\title{
Inserção competitiva da indústria brasileira de bens de capital (IBBK) no mercado internacional no período de 2008-2016
}

\author{
Competitive insert of the brazilian industry of capital goods (IBBK) in the \\ international market for the period 2008-2016
}

\section{Anselmo Carvalho de OliveiraI}

\begin{abstract}
RESUMO
O presente trabalho analisou a inserção no mercado internacional da indústria brasileira de bens de capital no período de 2008-2016. Foram realizadas análises descritivas sobre os valores das importações, exportações, saldos comerciais, participação nos fluxos internacionais totais, principais parceiros comerciais. Também foram calculadas a taxa de cobertura, as vantagens comparativas reveladas e a participação de mercado. Os resultados mostraram que o Brasil é um importador líquido de bens de capital e apresentou déficits na balança comercial do setor. Somente o subsetor de transporte apresentou um desempenho positivo e acumulou superávits comerciais. As exportações e as importações brasileiras de todos os subsetores analisados estão concentradas em poucos países; entre os principais importadores do Brasil destacam-se a Argentina, os Estados Unidos e o Chile.
\end{abstract}

Palavras-chave: Importação; Bens de capital; Inserção internacional; Competitividade

\section{ABSTRACT}

The present study analyzed the insertion in the international market of the Brazilian capital goods industry in the period 2008-2016. More general descriptive analyzes were carried out on the values of imports, exports, trade balances, participation in total international flows, main trading partners. We also calculated the index to measure the coverage rate, revealed comparative advantages and market share. The results showed that Brazil is a net importer of capital goods and consistently presents deficits in the trade balance of the sector. Only the transportation subsector performs positively and has accumulated trade surpluses. Brazilian exports and imports of all subsectors analyzed are concentrated in few countries. Among the main buyers of capital goods in Brazil are Argentina, the United States and Chile.

Key words: Import; Capital goods; International insertion; Competitiveness 


\section{INTRODUÇÃO}

No início da década de 1980, o Brasil possuía um parque industrial de bens de capital bastante diversificado, verticalizado e de baixa escala de produção. A produção recebia proteção do Governo, mas não apresentava níveis de eficiência e competitividade para buscar maior inserção no mercado internacional (ARAUJO, 2009; VERMULM, 1995).

Os padrões de instalação e expansão do setor não viabilizaram a sua operacionalização como fator de geração de um movimento endógeno de desenvolvimento e difusão de progresso tecnológico e inovações, como aconteceu nos países industrializados e desenvolvidos (RESENDE, ANDERSON, 1999).

Na década de 1990, com a abertura comercial, o Brasil iniciou um processo de aumento da indústria por meio de uma melhor alocação intersetorial de recursos, redução das empresas ineficientes e acesso a insumos e bens de capital mais baratos e de melhor qualidade. As principais mudanças nas orientações gerais da política econômica foram: a) abertura do mercado interno, com a eliminação das proibições e das licenças de importações, das medidas não-tarifárias e dos regimes especiais de importação e com a redução das tarifas médias de 57,5\% em 1987 para 32,2\% em 1990 e para $11,2 \%$ no final de 1994; b) privatizações; c) redução das taxas de inflação e estabilização macroeconômica com o Plano Real (ABREU, WERNECK, 2014).

Em 1990, com o Plano Collor I, a indústria apresentou forte retração, o que afetou particularmente 0 setor de bens de capital. A demanda por bens importados foi favorecida: pela redução das tarifas, em média, de 16,7 pontos percentuais para o setor (CASTRO, 2011); pela aceleração da atividade econômica entre 1993-1996 e a retomada do investimento externo; e pela forte apreciação cambial entre 1994-1999.

O padrão das importações mudou ao deixar de ser direcionado para compras de produtos sem similares nacionais para produtos concorrentes e substitutos (ARAUJO, 2009).

O setor reestruturou-se com o objetivo de aumentar a sua competividade. As empresas reduziram as linhas de produção e a verticalização, adotaram novas estratégias administrativas e técnicas organizacionais, reduziram o número de trabalhadores, aumentaram a especialização produtiva e substituíram a produção nacional, sobretudo, de peças e componentes por produtos importados (RESENDE, ANDERSON, 1999).

Com a nova conjuntura macroeconômica, entre 1994-1997, a formação bruta de capital fixo (FBKF) ampliou-se $18,4 \%$, mas o item máquinas e equipamentos nacionais encolheu $18,8 \%$, enquanto o item máquinas e equipamentos importados cresceu $107,6 \%$ (LAPLANE, SARTI, 1999; WEISE, 2000).

Os investimentos cresceram e foram importantes na modernização das empresas. Entre 1994-1997, os investimentos responderam positivamente à estabilização econômica com aumento de 14,5\% em 1992 para $18 \%$ do PIB no último trimestre de 1997. Os investimentos estrangeiros aumentaram o fluxo total de US\$730 milhões em 1990 para US\$ 21,887 bilhões dos quais US\$17,048 bilhões foram diretos (ID). 0 problema foi a concentração desses investimentos, principalmente no setor de serviços, com cerca de $83,7 \%$ do total contra $13,3 \%$ destinados à indústria (LAPLANE, SARTI, 1999).

Segundo Weise (2000), as empresas estrangeiras instaladas no país passaram a importar insumos e componentes básicos dos seus países de origem cujas consequências foram a desagregação da cadeia produtiva nacional e o bloqueio da formação de novas cadeias nesses setores; também não aconteceu grande transferência tecnológica para o 
país. A indústria nacional acabou ficando na margem do processo de inovação do setor, pois as transferências ocorreram, sobretudo, em técnicas e processos de produção maduros.

A abertura comercial iniciada nos anos de 1990 promoveu uma especialização tanto da cadeia produtiva quanto da estrutura das exportações e importações do país. Houve o aumento das importações dos bens de capital para suprir a demanda interna. E o aumento do fluxo de investimentos estrangeiros foi acompanhado de uma inexpressiva inserção internacional das empresas brasileiras, o que revelaria, por um lado, a falta de competitividade da indústria nacional e, por outro, reforçaria a ideia de desnacionalização da cadeia produtiva do setor.

Nesse contexto, o objetivo do artigo foi investigar a inserção internacional da indústria brasileira de bens de capital (IBBK) no período recente (entre 2008-2016).

$O$ texto estrutura-se em quatro seções, além dessa introdução e das considerações finais. Na próxima seção, apresenta-se uma nota metodológica sobre os caminhos percorridos na pesquisa; na terceira, foi discutido a inserção brasileira no comércio mundial desses produtos; a quarta, foram analisadas as vantagens comparativas reveladas do setor; e a última seção foi dedicada à análise sobre a participação de mercado do país.

\section{NOTA METODOLÓGICA}

$\mathrm{Na}$ literatura econômica, bens de capital são definidos, genericamente, como maquinas e equipamentos utilizados para produzir bens ou prover serviços, sem que sejam incorporados ao produto final ou destruídos durante o processo (portanto, diferemse dos insumos). Existem variações na agregação dos bens de capital que dificultam a coleta dos dados e a sua comparação entre diferentes períodos de tempo e estudos publicados. Segundo Vermulm (2003), no nível microeconômico, o mercado de bens de capital é significativamente heterogêneo e caracteriza-se como uma abstração quando analisado de forma totalmente desagregada ${ }^{1}$.

Para evitar esses problemas, a classificação adotada nesta pesquisa utiliza o relatório de produtos do İ́ndice Especial Bens de Capital da Pesquisa Industrial Mensal Produção Física (PIM-PF), realizada pelo Instituto Brasileiro de Geografia e Estatística (IBGE). Os produtos foram subdivididos em setores: Seriados, Não Seriados, Agrícola, Construção, Energia Elétrica, Transporte e de Uso Misto.

Os dados para os fluxos comerciais (CIF) foram extraídos a seis dígitos na classificação HS. A amostra de 284 produtos listados como bens de capital nesta pesquisa representa $27.26 \%$ dos todos os produtos classificados no grupo UNCATAD-SoP-4

\footnotetext{
1. O cuidado com relação à delimitação dos produtos e das atividades analisadas em uma pesquisa sobre o setor de bens de capital é relevante em três aspectos: 1) em razão da sua heterogeneidade, a escolha dos produtos tem profundas implicações sobre os resultados dos índices e estimações; 2) Uma definição muito abrangente implica na inclusão de produtos ou atividades, principalmente as que envolvem a produção de peças ou a prestação de serviços de manutenção e instalação, que não são, stricto sensu, bens de capital. Por outro lado, uma definição muito restritiva implica em grande volume de informações e na dificuldade para se obter todos os dados sobre as diferentes variáveis que são relevantes para uma análise abrangente do setor. 3) Como cada pesquisa caracteriza o setor de uma forma, é difícil estabelecer comparações entre os resultados obtidos, o que prejudica a acumulação do conhecimento na área.
} 
Consolidado de bens de capital. Para as exportações foram usados dados espelhados das importações (CIF) dos países com os quais o Brasil realizou comércio².

A compatibilização dos produtos e atividades entre os diferentes sistemas utilizou a PRODLIST Indústria 2013 e 2016, o volume 38 do Relatório Metodológico - IPP para Indústria de Transformação e as tabelas de compatibilidade da Comissão Nacional de Classificação (CONCLA).

Os valores em dólares foram deflacionados para o ano base de 2010 pelo Índice de Preços por Atacado - Oferta Global -, Indústria (IPA-OG) calculado pela Fundação Getúlio Vargas (FGV), salvo quando explicitado de forma diferente ou quando os dados forem citados com base em pesquisas de terceiros.

Para responder ao problema de pesquisa, foram realizadas análises descritivas sobre os valores das importações, exportações, saldos comerciais, participação nos fluxos internacionais totais, principais parceiros comerciais, participação de mercado e índice de vantagem comparativa revelada de Lafey (IVCRL).

De acordo com Lafay (1992), a vantagem comparativa é um conceito estrutural no qual é importante eliminar as influências de variáveis macroeconômicas que possam causar desequilíbrios conjunturais ou não estruturais no balanço de pagamentos.

Para eliminar esses desequilíbrios, considera-se um balanço da conta corrente "normal" para o país - aquela compatível com os movimentos estruturais de capital -, o seu desenvolvimento relativo e a sua importância econômica. Na prática, contudo, tomase como referência um saldo zero de equilíbrio na conta corrente ou comercial ${ }^{3}$. Para calcular o saldo zero, atribui-se a cada indústria ou setor um peso no déficit ou superávit da balança comercial do país; para eliminar as mudanças dos padrões de comércio mundial do setor $k$ que afetam o comércio do país $\mathrm{j}$ do setor $k$, mas que não podem ser interpretadas como mudanças nas (des)vantagens comparativas do país, o IVCRL é normalizado pelo fator einmun antes da agregação (LAFAY, 1992).

$I V C R L=1000 *\left(\frac{X_{k}^{j}-M_{k}^{j}}{P I B^{j}}\right)-\frac{\left(X_{k}^{j}+M_{k}^{j}\right)}{\left(X^{j}+M^{j}\right)} * 1000 *\left(\frac{X^{j}-M^{j}}{P I B^{j}}\right)$

$\mathrm{X}^{\mathrm{j}}$ - exportações totais do país $\mathrm{j}$ no ano analisado $\mathrm{t}$.

$\mathrm{M}^{\mathrm{j}}$ - Importações totais do país $\mathrm{j}$ no ano analisado t.

$X_{k}{ }^{j}$ - exportações do setor $k$ do país $\mathrm{j}$ no ano analisado t.

$M_{k}{ }^{j}$ - exportações do setor $k$ do país $j$ no ano analisado $t$.

PIB - Produto Interno Bruto do país j no ano analisado t.

Para eliminar mudanças dos padrões de comércio mundial do setor i que afetam o comércio, o IVCRL é normalizado pelo fator as einmun antes da agregação (LAFAY, 1992).

2. Existe uma diferença nos valores dos dados CIF e FOB. A escolha entre dados CIF e FOB refletem diretamente sobre o saldo da balança de pagamentos e sobre os índices calculados na pesquisa. Nesta pesquisa, particularmente, optou-se por dados das importações (CIF) e dados espelhados para as exportações.

3. É preferível adotar a conta corrente como referência para a análise, segundo Lafay (1992), porque os desequilíbrios mais graves decorrem do fluxo de mercadorias e também porque os fluxos comerciais apresentam menores erros sistemáticos de mensuração. 
$e_{k n}^{m u n}=\frac{\left(X_{k n}^{m u n}+M_{k n}^{m u n}\right) /\left(X_{n}^{m u n}+M_{n}^{m u n}\right)}{\left(X_{k}^{m u n}+M_{k}^{m u n}\right) /\left(X^{m u n}+M^{m u n}\right)}$

$\mathrm{X}_{k n}{ }^{\text {mun }}$ - Exportações do setor $\mathrm{k}$ do mundo no ano base $\mathrm{n}$.

$\mathrm{M}_{k n}{ }^{\text {mun }}$ - Importações do setor $\mathrm{k}$ do mundo no ano base $\mathrm{n}$.

$\mathrm{X}_{n}{ }^{\mathrm{mun}}$ - Exportações totais do mundo no ano base $\mathrm{n}$.

$\mathrm{M}_{n}{ }^{\text {mun }}$ - Importações totais do mundo no ano base $\mathrm{n}$.

$\mathrm{X}_{k}{ }^{\text {mun }}$ - Exportações do setor $\mathrm{k}$ do mundo no ano analisado $\mathrm{t}$.

$\mathrm{M}_{k}$ mun - Importações do setor $\mathrm{k}$ do mundo no ano analisado $\mathrm{t}$

$\mathrm{X}^{\text {mun }}$ - Exportações totais do mundo no ano analisado t.

$\mathrm{M}^{\text {mun }}$ - Importações totais do mundo no ano alisado $\mathrm{t}$.

A taxa de cobertura setorial é um indicador que revela a porcentagem das importações desagregadas por setor do país paga pelas exportações do mesmo setor: $T C S=\frac{X_{k}^{j}}{M_{k}^{j}}$. A taxa de cobertura normalizada pondera a taxa de cobertura setorial pela taxa de cobertura da economia: ${ }_{T C S N}=\frac{X_{k}^{j}}{M_{k}^{j}} / \frac{X^{j}}{M^{j}}$.

Para calcular a participação de mercado, optou-se por agrupar as exportações em períodos e utilizar os valores médios nesses períodos para verificar a composição da pauta. Esse procedimento evita a distorção dos resultados por mudanças anuais muito drásticas - uma marca de alguns anos do período analisado (GRAMS et al., 2013). A participação de mercado do Brasil é calculada pela soma das exportações brasileiras do setor para o país i sobre as importações totais do setor no país de referência i do resto do mundo: Share $=\frac{X_{k}^{j i}}{M_{k}^{i m u n}}$

\section{A INSERÇÃO COMPETITIVA DA IBBK NO MERCADO INTERNACIONAL}

A estrutura e o desenvolvimento recentes da IBBK afetaram positivamente a inserção no mercado internacional dos bens de capital brasileiros? O objetivo deste tópico é analisar os fluxos das exportações de bens de capital considerando a competitividade dos produtos nacionais.

Nas últimas três décadas, marcadas, sobretudo, pela abertura comercial, o equilíbrio macroeconômico, a apreciação cambial e o crescimento da demanda internacional por comodities naturais e minerais afetaram tanto a estrutura, quanto a direção dos fluxos comerciais brasileiros. Quanto à estrutura, a pauta de exportação se tornou, novamente, dominada por commodities agrícolas e mineiras e por bens de baixa intensidade tecnológica. O Brasil é um importador líquido de bens de capital e pouco integrado às cadeias globais do setor participando de apenas $0.94 \%$ das exportações e $1.25 \%$ das importações mundiais acumuladas durante o período, ocupando a $23^{\circ}$ em ambos os quesitos (Tabela 8; Tabela 9); quanto à direção, a China tornou-se o principal exportador para o Brasil e ocupou a posição historicamente dominada pelos Estados Unidos. Já os Estados Unidos ocuparam a posição de principal importador do Brasil ultrapassando a Argentina (Tabela 6). 
Em 2008, o fluxo mundial desses bens foi de cerca de US\$ 2,042,780,654.52 mil (a preços constantes de 2010). O Brasil participou com $1.23 \%$ das exportações e $1.25 \%$ das importações mundiais. Em 2016, o fluxo mundial cresceu para US\$2,380,399,176.16 mil, no entanto, a participação brasileira caiu para $0.84 \%$ e $0.94 \%$ respectivamente. Os maiores importadores e exportadores mundiais são a China, Alemanha e Estados Unidos (Tabela 8 ; Tabela 9).

As exportações brasileiras no período reduziram cerca de $20.78 \%$, de US $\$$ 25,193,017.15 mil em 2008 para US\$19,958,269.91 mil em 2016 (Figura 1). Todos os setores, exceto o de transporte, apresentaram forte redução, com queda de $75.97 \%$ no setor de bens de capital de uso misto, $40.47 \%$ no de construção e $40.39 \%$ de não seriados.

O subsetor de transporte respondeu, em valores acumulados, por $45.38 \%$ das exportações brasileiras e o subsetor de construção por $20.63 \%$. Os movimentos dos subsetores após 2014 são relevantes para entender esses números. O subsetor de transporte aumentou suas vendas em $29.92 \%$, frente a reduções superiores a $20 \%$ dos setores de bens seriados, agrícola e construção (em 2016 frente 2014).

Alguns fatores podem ter pesado para a queda nas exportações: a) a crise financeira afetou a demanda pelos bens brasileiros no mercado internacional, com a maior redução percentual em 2009; b) os custos aumentaram acima do valor bruto da produção industrial (VBP), sobretudo, a partir de 2012, o que pode ter reduzido a atratividade do setor para novos investimentos ${ }^{4}$; c) as constantes valorizações da taxa de câmbio entre 2009-2014;d) as exportações brasileiras apresentam uma grande concentração de mercado. A Argentina respondeu por $23.08 \%$ do total acumulado das exportações no período, os EUA por $19.51 \%$ e o terceiro colocado, o México, respondeu por apenas $6.48 \%$ (Tabela 6). Os cinco principais importadores respondem por $58.88 \%$. O desempenho das exportações ficou vulnerável aos problemas econômicos nos maiores mercados, sobretudo, Argentina e EUA.

No período, as compras da Argentina reduziram em $30.76 \%$. O subsetor de Uso Misto teve uma redução de $97.79 \%$ e o de construção de $37.17 \%$. Uma explicação para essa redução foi o desempenho da economia argentina no período, com um crescimento médio anual negativo a partir de 2012 e a depreciação do peso frente ao real e ao dólar a partir de 2013-2014. A perda só não foi maior pelo crescimento das exportações de bens não seriados e pela recuperação do subsetor de transportes em 2016 para esse mercado.

As compras americanas dos bens de capital do Brasil, por sua vez, reduziram-se em $9.02 \%$ no período como consequência da crise de 2008 . As compras americanas caíram $53.07 \%$ em 2009 em relação ao ano anterior e retomaram uma lenta trajetória de crescimento, mas insuficiente para alcançar os patamares de importações anteriores à crise.

As importações brasileiras, por sua vez, reduziram-se $12.61 \%$ de US\$ 25,594,336.99 mil em 2008 para US\$22,366,192.81 mil em 2016 (Figura 1). A crise de 2009 e a de 2015-2016 estão entre os fatores relevantes que explicam esse resultado. Os cinco maiores parceiros, que representam $61.68 \%$ do total, reduziram as suas vendas para

4. A redução da rentabilidade da IBBK contrasta com o aumento da rentabilidade do setor de exportação de commodities. Esse contraste faz com que os setores ligados às commodities sejam mais atrativos para os investimentos levando ao aumento, no futuro, da participação na estrutura produtiva do país (NEGRI, ALVARENGA, 2010). 
o Brasil em 2016 frente a 2013 em: 30.17\% (China), 45.14\% (EUA), 52.97\% (Argentina), 38.16\% (Alemanha), 51.19\% (Japão).

A utilização da capacidade instalada (UCI) abaixo de $80 \%$ em 2015-2016, exceto para o subsetor de fabricação de outros veículos de transporte (exclusive automotores), e a falta de perspectiva de retomada rápida sinalizavam que não seriam necessários investimentos para a expansão da capacidade produtiva nos curto e médio prazos. Concomitantemente, o movimento de depreciação acentuado do câmbio encareceu os produtos importados.

No entanto, os setores de bens seriados, com variação positiva de $65.53 \%$, e de energia elétrica, com $20.83 \%$, apresentaram crescimento nas importações. A produção nacional nesses setores também cresceu, como mostra a análise do VBP, mas a demanda interna, mesmo com a crise, continuou dependendo da oferta externa para ser atendida em bens de alta intensidade tecnológica do setor elétrico e de máquinas e equipamentos industriais feitos sob encomenda.

A pauta das importações brasileiras concentrava-se em três subsetores: bens seriados, construção e transporte, que responderam por $68.40 \%$ do total importado.

Figura 1 - Variação do total exportado e importado e valor da exportação, da importação, do saldo comercial (Mil US\$2010 constante)

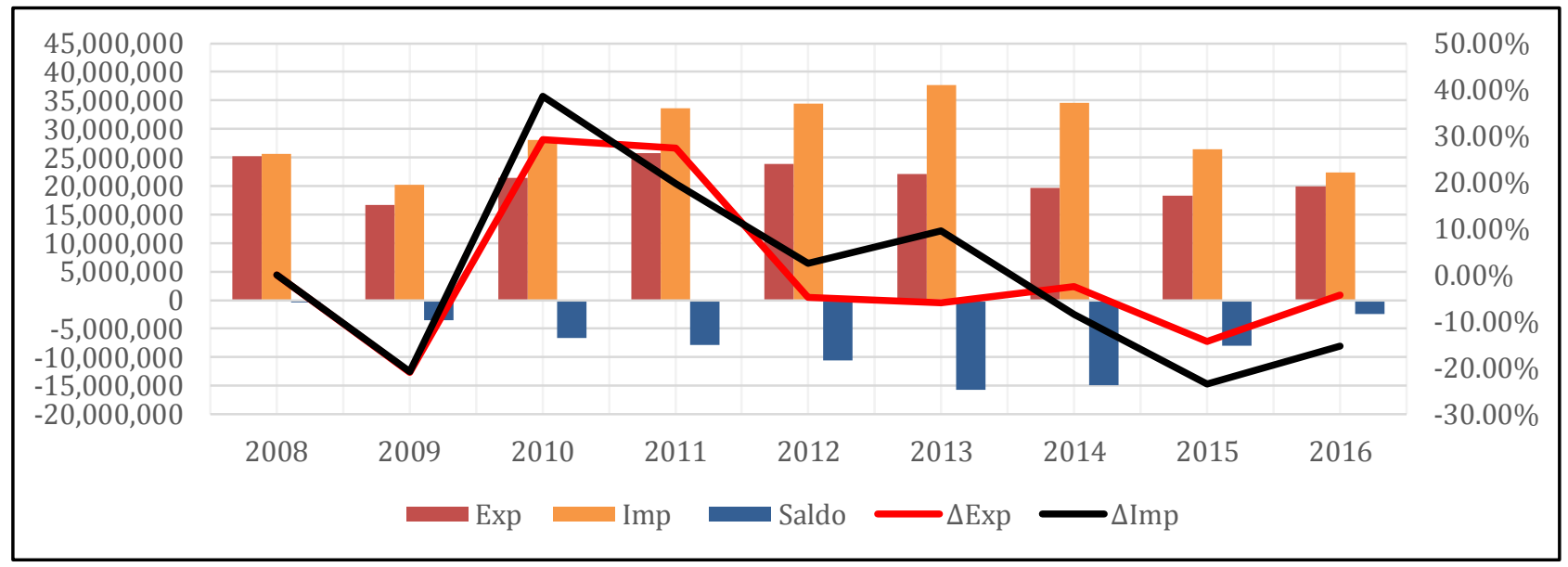

Fonte: Resultados da pesquisa, dados do CONTRADE

O déficit comercial do setor cresceu de US\$ 401,319.84 mil em 2008 para US\$ $2,407,922.90$ mil em 2014. O déficit acumulado no período foi de US $\$$ $70,171,519.65$ mil. Entre 2015-2016, os déficits foram menores do que os máximos alcançados em 2013-2014, explicado, principalmente, pela redução das importações, que foram $35.22 \%$ menores e as exportações, $1.78 \%$ maiores em 2016 frente a 2014.

Entre os subsetores, no acumulado do período, o único que apresentou superávit foi o de transportes, e o setor de bens industriais seriados teve o maior déficit (Figura 2). 
Figura 2 - Balança Comercial por setorial - resultados acumulados entre 2008-2016 (Mil US\$2010 Constante)

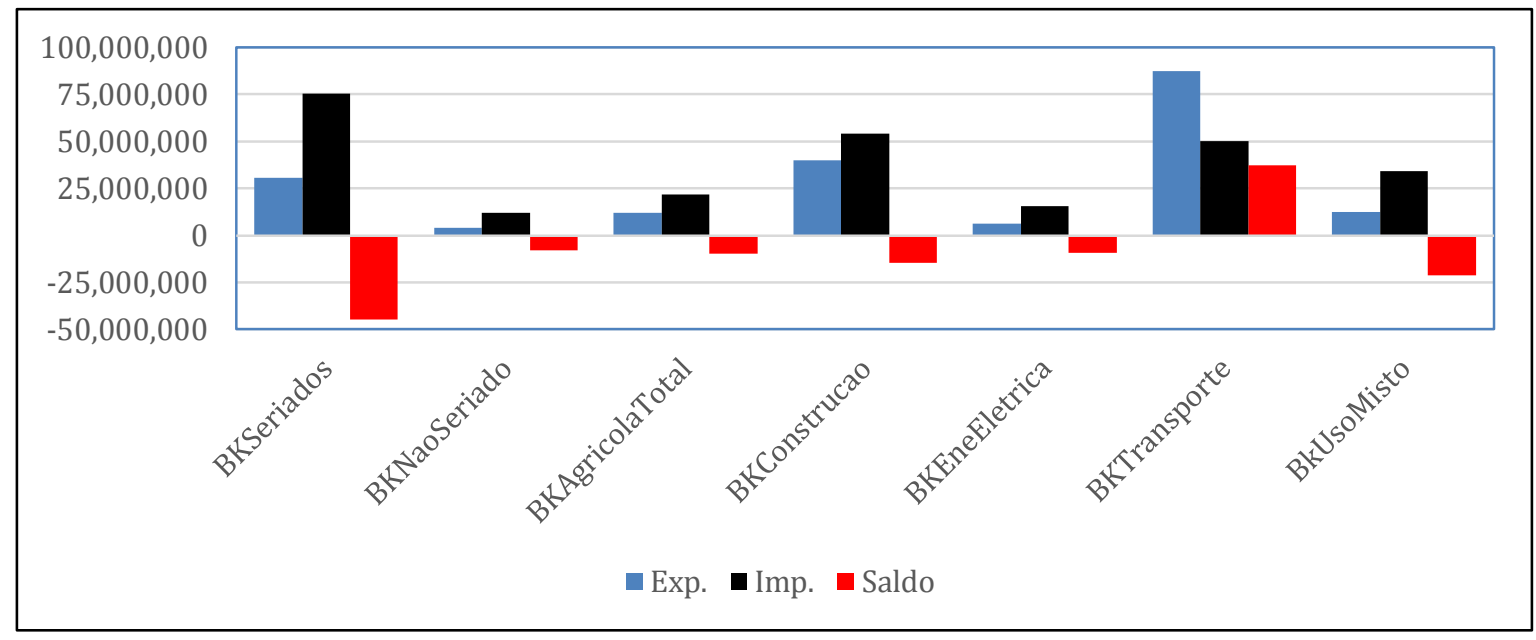

Fonte: Resultados da Pesquisa, dados do CONTRADE

A evolução das taxas de cobertura normalizada (Tabela 1) indica que todos os subsetores perderam competitividade no período e que, exceto o subsetor de transporte, os demais são deficitários. Os subsetores de Uso Misto, Não Seriado e Energia Elétrica são os que apresentam as menores capacidades de pagamento, embora não tenham apresentado os maiores déficits brutos (Figura 2) em razão da participação no total do comércio ser menor do que o setor de bens seriados.

Em contraste com o setor de bens de capital, a taxa de cobertura geral da economia evoluiu positivamente até $142.63 \%$ de capacidade de pagamento das importações pelas exportações em 2016 (Tabela 2). A análise dos índices de cobertura total da economia em conjunto com o índice de cobertura setorial normalizada permite sugerir que os problemas estruturais e/ou conjecturais específicos associados ao setor de bens de capital foram impactados com maior intensidade do que o resto da economia com as crises de 2008 e de 2014-2016.

Tabela 1 - Taxa de Cobertura Setorial Normalizada (em \%)

\begin{tabular}{lrrrrrrrrr}
\hline & $\mathbf{2 0 0 8}$ & \multicolumn{1}{c}{$\mathbf{2 0 0 9}$} & $\mathbf{2 0 1 0}$ & $\mathbf{2 0 1 1}$ & $\mathbf{2 0 1 2}$ & $\mathbf{2 0 1 3}$ & $\mathbf{2 0 1 4}$ & $\mathbf{2 0 1 5}$ & $\mathbf{2 0 1 6}$ \\
\hline BK Total & 83.98 & 66.05 & 66.24 & 64.81 & 61.09 & 58.01 & 55.11 & 58.30 & 62.56 \\
Seriados & 40.18 & 37.44 & 35.06 & 34.64 & 34.39 & 34.80 & 36.10 & 34.36 & 31.94 \\
Não Seriado & 59.11 & 26.10 & 32.04 & 35.17 & 24.27 & 21.73 & 29.47 & 27.88 & 17.49 \\
Agricola & 50.54 & 48.83 & 50.39 & 49.10 & 46.32 & 47.44 & 48.74 & 48.02 & 38.60 \\
Construcão & 90.20 & 63.40 & 68.16 & 68.34 & 64.32 & 57.58 & 58.36 & 56.71 & 50.17 \\
Ene. Elétrica & 49.75 & 57.82 & 44.87 & 36.02 & 30.30 & 31.29 & 31.37 & 27.41 & 25.47 \\
Transporte & 201.34 & 143.94 & 154.70 & 169.05 & 149.17 & 131.09 & 114.57 & 130.87 & 188.31 \\
Uso Misto & 68.61 & 61.94 & 37.89 & 23.19 & 24.54 & 24.43 & 14.12 & 19.37 & 19.23 \\
\hline
\end{tabular}

Fonte: Resultados da Pesquisa, dados do CONTRADE 
Os efeitos das duas crises reduziram as exportações do setor, que apresenta baixa competitividade no mercado internacional. Em 2009, todos os subsetores, exceto o de energia elétrica, reduziram as exportações e, em 2014-2016, somente os subsetores de transporte e de uso misto (que possuíam uma capacidade de pagamento muito baixa) não reduziram a sua cobertura normalizada. Por outro lado, no acumulado de todos os setores, as exportações foram suficientes para pagar as importações totais, sobretudo, pelos saldos positivos do setor de bens primários no qual o país possuí vantagens comparativas (HIDALGO, FEISTEL, 2013; NEGRI, ALVARENGA, 2010; OLIVEIRA, 2019).

Tabela 2 - Taxa de Cobertura Setorial em valores constantes de 2010 ( em \%)

\begin{tabular}{lrrrrrrrrr}
\hline & $\mathbf{2 0 0 8}$ & $\mathbf{2 0 0 9}$ & $\mathbf{2 0 1 0}$ & $\mathbf{2 0 1 1}$ & $\mathbf{2 0 1 2}$ & $\mathbf{2 0 1 3}$ & $\mathbf{2 0 1 4}$ & $\mathbf{2 0 1 5}$ & $\mathbf{2 0 1 6}$ \\
\hline Todos & 117.21 & 124.94 & 114.89 & 118.02 & 113.50 & 100.69 & 103.07 & 119.30 & 142.63 \\
Produtos & 98.43 & 82.52 & 76.11 & 76.49 & 69.34 & 58.41 & 56.80 & 69.55 & 89.23 \\
BK Total & 47.10 & 46.78 & 40.28 & 40.89 & 39.03 & 35.04 & 37.20 & 41.00 & 45.56 \\
Seriados & 69.28 & 32.61 & 36.81 & 41.50 & 27.55 & 21.88 & 30.37 & 33.26 & 24.95 \\
Não Seriado & 59.24 & 61.00 & 57.89 & 57.95 & 52.57 & 47.77 & 50.24 & 57.29 & 55.05 \\
Agrícola & 105.72 & 79.21 & 78.31 & 80.65 & 73.00 & 57.98 & 60.15 & 67.66 & 71.56 \\
Construção & 58.31 & 72.24 & 51.55 & 42.51 & 34.39 & 31.51 & 32.33 & 32.70 & 36.33 \\
Ene. Elétrica & 236.00 & 179.84 & 177.74 & 199.52 & 169.30 & 131.99 & 118.09 & 156.13 & 268.59 \\
Transporte & 80.41 & 77.39 & 43.53 & 27.37 & 27.85 & 24.60 & 14.56 & 23.11 & 27.43 \\
Uso Misto & & & & & & & & & \\
\hline
\end{tabular}

Fonte: Resultados da pesquisa, dados CONTRADE

\section{VANTAGENS COMPARATIVAS}

A abordagem das vantagens comparativas propostas inicialmente por Balassa e desenvolvida por vários autores parte do pressuposto que o comércio internacional é a expressão das vantagens que um país possui na produção de algum bem e as importações, por sua vez, revelam as limitações produtivas do país. Essas vantagens e desvantagens estão refletidas diretamente nos saldos comerciais que, devidamente transformados, oferecem uma imagem sintética das (des)vantagens do produto, indústria ou setor analisado. $\mathrm{O}$ índice de vantagem comparativa revelada de Lafay (IVCRL) é parte do grupo dos índices que aprofundaram a abordagem de Balassa.

Lafay (1992, p. 227-230) identificou que, no período entre 67-86, aconteceu uma reversão "espetacular" nas vantagens comparativas do Brasil no setor de bens primários. O setor possuía forte vantagem até $1975-1977$, mas terminou o período com forte desvantagem, explicada, sobretudo, pela perda das vantagens agrícolas e pela dependência energética.

Oliveira (2019) calculou o IVCRL, no período de 1989-2016 (ano base 2010), para os quatro grandes setores de atividade (bens primários, consumo, intermediário e de capital $^{5}$ ) e identificou que, a partir de 1993, o país voltou a reverter as desvantagens nos bens primários, consolidando grandes vantagens comparativas no setor. Para os bens

5. Oliveira (2019) utilizou como referências a diferença de saldo com dados CIF e FOB e todos os bens classificados no grupo UNCTAD-SoP4. A amostra utilizada nessa pesquisa corresponde a $28 \%$ dos bens nesse grupo. 
intermediários, o Brasil possuía um padrão de especialização com vantagens comparativas, que se reduziu sistematicamente, apresentando desvantagens a partir de 2008. Para os bens de consumo, o país possuía desvantagem comparativa, que foi revertida, de acordo com os dados de Lafay (1992), a partir de 1973. O setor se manteve com vantagens até 2006, quando novamente apresentou redução, que se aprofundou rapidamente até 2016.

Com relação ao setor de bens de capital, Lafay (1992) mostrou que o país apresentou desvantagens em todo o período entre 1967-1986, mas com uma tendência de redução a partir de 1974. O Brasil nunca apresentou, de acordo com o IVCRL, vantagens no setor de bens de capital (LAFAY, 1992; OLIVEIRA, 2019)

Os resultados desta pesquisa, para o grupo de bens analisados, confirmaram que o país possuía desvantagens no setor de bens de capital, mas que no subsetor de transportes, por outro lado, o país possuía vantagens. Todavia, é preciso salientar que o setor é dominado por empresas multinacionais inseridas nas cadeias globais de valor, que desenvolvem grande parte dos seus projetos de engenharia e de inovação tecnológica fora do país (PEDRO, BARROS, 2011).

O movimento em direções contrárias apresentado pelo IVCRL do setor de bens primários e de bens de capital são reflexos do desenvolvimento estrutural ao longo da história da economia nacional (mesmo no setor automotivo no qual possui vantagens comparativas), sobretudo, após a abertura comercial e a crise cambial de 1999.

Delgado (2010) argumentou que o país, na década de 2000, realizou três movimentos interconectados que levaram à especialização em bens primários do comércio exterior: a) uma nova inserção do Brasil na divisão internacional do trabalho como exportador de commodities para responder aos desafios da dependência de recursos externos, que foram desencadeados pela crise de 1999; b) a reestruturação política do Estado em torno do agronegócio por meio de estímulos à expansão das cadeias agroindustriais e do mercado de crédito público subsidiado e valorização das terras; c) a extração de lucros extraordinários da propriedade da terra e dos recursos naturais incentivando o investimento na exploração desses recursos. As vantagens comparativas em bens primários associada à demanda externa por commodities intensificaram a acumulação e fizeram com que investimentos nesse setor se tornassem mais atrativos do que na indústria. 
Tabela 3 - Índice de Vantagem Comparativa Revelada de Lafay em valores correntes (IVCRL)

\begin{tabular}{lccccccc}
\hline & Seriado & $\begin{array}{c}\text { Não } \\
\text { seriado }\end{array}$ & Agrícola & Construção & Energia Elétrica & Transporte & Uso Misto \\
\hline 2008 & -2.7750 & -0.2077 & -0.7405 & -0.1514 & -0.4657 & 2.6706 & -0.7720 \\
2009 & -2.3702 & -0.5308 & -0.5653 & -0.5161 & -0.3203 & 1.0561 & -0.7320 \\
2010 & -2.6035 & -0.4494 & -0.5510 & -0.4332 & -0.3934 & 1.4011 & -1.1233 \\
2011 & -2.6929 & -0.3749 & -0.5917 & -0.4393 & -0.5289 & 1.7481 & -1.4901 \\
2012 & -2.7641 & -0.4828 & -0.6605 & -0.5519 & -0.6434 & 1.3595 & -1.4202 \\
2013 & -2.7482 & -0.6138 & -0.6759 & -0.6878 & -0.6139 & 0.9953 & -1.3329 \\
2014 & -2.3696 & -0.3801 & -0.5515 & -0.5674 & -0.6012 & 0.4961 & -1.5615 \\
2015 & -2.7010 & -0.4033 & -0.5738 & -0.5914 & -0.6953 & 1.0890 & -1.5748 \\
2016 & -2.5301 & -0.8178 & -0.6872 & -0.6073 & -0.6805 & 2.3469 & -1.4461 \\
\hline
\end{tabular}

Fonte: Resultados da pesquisa, dados do CONTRADE e Word Bank

Hidalgo e Feistel (2013), com base no modelo Heckscher-Ohlin, mostraram que depois da abertura comercial, a participação dos produtos primários no comércio internacional cresceu com altas taxas e alcançou a participação de $50 \%$ no total exportado em 2010. Já os produtos manufaturados reduziram a sua participação nesse total. Esses resultados indicariam a tendência de crescimento da participação de produtos intensivos em recursos naturais e menor participação de bens intensivos em trabalho e em capital na pauta de exportações brasileiras.

Nessa linha de análise, a pauta de comércio exterior apresenta tendência de longo prazo de especialização na produção de bens intensivos nos recursos no qual a economia brasileira é abundante, isto é, terras e minerais (recursos naturais) em relação aos seus principais parceiros comerciais. Essa especialização seria o reflexo das vantagens comparativas estáticas do país diante da maior liberdade comercial e da eliminação de mecanismos de política industrial, que distorciam parte da alocação dos recursos antes da abertura comercial (HIDALGO, FEISTEL, 2013).

A especialização em bens primários deixou a economia brasileira vulnerável às variações e à deterioração dos termos de troca cujos efeitos negativos sobre o balanço de pagamentos podem restringir o crescimento no longo prazo (LAUTENSCHLAGER, 2017). Ademais, essa especialização pode levar, no médio e longo prazo, ao aumento da dependência das importações nos outros setores, particularmente de bens de capital, no qual o país apresenta desvantagens comparativas.

\section{PARTICIPAÇÃO DE MERCADO}

As exportações de bens de capital tiveram um desempenho médio inferior às exportações totais brasileiras no período e às exportações mundiais do setor. No primeiro período (2008-2010/2011-2013), as exportações brasileiras cresceram, mas ficaram aquém do crescimento das exportações mundiais. Já no segundo período (20112013/2014-2016), as exportações brasileiras diminuíram 19.14\% (Tabela 4). As exportações brasileiras do setor no segundo período caíram $35.97 \%$ para a Argentina e $32.65 \%$ para o Chile. Essas reduções somente não foram maiores do que a queda das exportações para a Alemanha, de $42.95 \%$. 
O Brasil perdeu participação nos seis principais mercados de exportação, reduzindo o total exportado em $49.66 \%$. No mercado argentino, a redução da participação brasileira foi de 9.51 pontos percentuais e no mercado chileno foi de 3.19 pontos percentuais.

Tabela 4 - Participação de Mercado do Brasil (Mil US\$ 2010 constante)

\begin{tabular}{|c|c|c|c|c|c|}
\hline & & EUA & Alemanha & China & México \\
\hline \multirow{3}{*}{$2008-2010$} & Importação Total BK & $308,473,323$ & $163,295,312$ & $99,916,970$ & $54,695,011$ \\
\hline & Exportação Brasil BK & $3,739,915$ & $1,125,300$ & 581,820 & $1,318,698$ \\
\hline & Market share & $1.21 \%$ & $0.69 \%$ & $0.58 \%$ & $2.41 \%$ \\
\hline \multirow{3}{*}{$2011-2013$} & Importação Total BK & $403,191,504$ & $189,403,517$ & $131,597,448$ & $75,129,940$ \\
\hline & Exportação Brasil BK & $3,769,986$ & $1,206,355$ & 905,637 & $1,507,801$ \\
\hline & Market share & $0.94 \%$ & $0.64 \%$ & $0.69 \%$ & $2.01 \%$ \\
\hline \multirow{7}{*}{$2014-2016$} & Importação Total BK & $462,663,497$ & $186,845,189$ & $133,032,685$ & $83,350,869$ \\
\hline & Exportação BK Brasil & $4,873,357$ & 688,211 & 722,008 & $1,289,428$ \\
\hline & Market share & $1.05 \%$ & $0.37 \%$ & $0.54 \%$ & $1.55 \%$ \\
\hline & $\begin{array}{l}\text { Crescimento importações BK } \\
\text { do período } 1 \text { para o } 2\end{array}$ & $30.71 \%$ & $15.99 \%$ & $31.71 \%$ & $37.36 \%$ \\
\hline & $\begin{array}{l}\text { Crescimento Exportações do } \\
\text { Brasil de BK do período } 1 \text { para } \\
\text { o } 2\end{array}$ & $0.80 \%$ & $7.20 \%$ & $55.66 \%$ & $14.34 \%$ \\
\hline & $\begin{array}{l}\text { Crescimento importações BK } \\
\text { do período } 2 \text { para o } 3\end{array}$ & $14.75 \%$ & $-1.35 \%$ & $1.09 \%$ & $10.94 \%$ \\
\hline & $\begin{array}{l}\text { Crescimento Exportações do } \\
\text { Brasil BK do período } 2 \text { para o } 3\end{array}$ & $29.27 \%$ & $-42.95 \%$ & $-20.28 \%$ & $-14.48 \%$ \\
\hline
\end{tabular}

\begin{tabular}{|c|c|c|c|c|c|}
\hline & & Argentina & Chile & $\begin{array}{c}\text { Total BK } \\
\text { Mundo }\end{array}$ & $\begin{array}{l}\text { Total } 6 \\
\text { maiores }\end{array}$ \\
\hline \multirow{3}{*}{ 2008-2010 } & Importação Total BK & $13,042,876$ & $10,743,800$ & $1,894,840,539$ & $650,167,293$ \\
\hline & Exportação Brasil BK & $4,947,353$ & $1,140,189$ & $21,086,349$ & $12,853,275$ \\
\hline & Market share & $37.93 \%$ & $10.61 \%$ & $1.11 \%$ & $1.98 \%$ \\
\hline \multirow{3}{*}{ 2011-2013 } & Importação Total BK & $15,116,075$ & $16,636,903$ & $2,451,305,149$ & $831,075,387$ \\
\hline & Exportação Brasil BK & $5,916,868$ & $1,233,977$ & $23,882,028$ & $14,540,624$ \\
\hline & Market share & $39.14 \%$ & $7.42 \%$ & $0.97 \%$ & $1.75 \%$ \\
\hline \multirow{7}{*}{ 2014-2016 } & Importação Total BK & $12,783,875$ & $13,503,920$ & $2,472,951,347$ & $892,180,035$ \\
\hline & Exportação BK Brasil & $3,788,282$ & $831,098.89$ & $19,312,176.76$ & $7,319,027.41$ \\
\hline & Market share & $29.63 \%$ & $6.15 \%$ & $0.78 \%$ & $0.82 \%$ \\
\hline & $\begin{array}{l}\text { Crescimento importações BK } \\
\text { do período } 1 \text { para o } 2\end{array}$ & $15.90 \%$ & $54.85 \%$ & $29.37 \%$ & $27.82 \%$ \\
\hline & $\begin{array}{l}\text { Crescimento Exportações do } \\
\text { Brasil de BK do período } 1 \\
\text { para o } 2\end{array}$ & $19.60 \%$ & $8.23 \%$ & $13.26 \%$ & $13.13 \%$ \\
\hline & $\begin{array}{l}\text { Crescimento importações BK } \\
\text { do período } 2 \text { para o } 3\end{array}$ & $-15.43 \%$ & $-18.83 \%$ & $0.88 \%$ & $7.35 \%$ \\
\hline & $\begin{array}{l}\text { Crescimento Exportações do } \\
\text { Brasil BK do período } 2 \text { para } \\
\text { o } 3\end{array}$ & $-35.97 \%$ & $-32.65 \%$ & $-19.14 \%$ & $-49.66 \%$ \\
\hline
\end{tabular}

Fonte: Elaborado pelo autor, dados CONTRADE 
Em 2008, o subsetor com maior participação na pauta de exportações de bens de capital (das importações pela Argentina.

Tabela 5) foi o de transportes (41.27\%), seguido de construção $(20.75 \%)$, seriado $(14.47 \%)$ e uso misto (12.22\%). No entanto, algumas mudanças significativas ocorrem na pauta no período estudado. Em 2016, a participação do subsetor de transportes cresceu para $56.69 \%$, o que pode ser explicado, sobretudo, pela retomada das importações pela Argentina.

Tabela 5 - Participação na Pauta

\begin{tabular}{lrrrrrrr}
\hline & Seriados & $\begin{array}{c}\text { Não } \\
\text { seriado }\end{array}$ & Agrícola & Construção & $\begin{array}{c}\text { Energia } \\
\text { Elétrica }\end{array}$ & Transporte & Uso Misto \\
\hline 2008 & $14.47 \%$ & $2.40 \%$ & $5.82 \%$ & $20.75 \%$ & $3.06 \%$ & $41.27 \%$ & $12.22 \%$ \\
2009 & $16.44 \%$ & $2.53 \%$ & $6.11 \%$ & $18.09 \%$ & $4.94 \%$ & $38.66 \%$ & $13.23 \%$ \\
2010 & $15.62 \%$ & $2.35 \%$ & $6.22 \%$ & $20.61 \%$ & $3.56 \%$ & $44.03 \%$ & $7.61 \%$ \\
Média & $15.38 \%$ & $2.42 \%$ & $6.03 \%$ & $20.00 \%$ & $3.73 \%$ & $41.51 \%$ & $10.93 \%$ \\
$2008-2010$ & $15.97 \%$ & $2.15 \%$ & $6.23 \%$ & $22.08 \%$ & $3.15 \%$ & $45.45 \%$ & $4.98 \%$ \\
2011 & $16.06 \%$ & $1.73 \%$ & $6.05 \%$ & $23.64 \%$ & $2.95 \%$ & $44.55 \%$ & $5.01 \%$ \\
2012 & $16.40 \%$ & $1.94 \%$ & $6.55 \%$ & $22.24 \%$ & $3.07 \%$ & $44.97 \%$ & $4.83 \%$ \\
2013 & $16.13 \%$ & $1.95 \%$ & $6.27 \%$ & $22.65 \%$ & $3.06 \%$ & $45.00 \%$ & $4.94 \%$ \\
Média & $18.09 \%$ & $2.05 \%$ & $6.91 \%$ & $21.81 \%$ & $3.48 \%$ & $44.42 \%$ & $3.25 \%$ \\
$2011-2013$ & $16.85 \%$ & $1.78 \%$ & $6.19 \%$ & $19.12 \%$ & $3.10 \%$ & $48.93 \%$ & $4.04 \%$ \\
2014 & $14.14 \%$ & $1.81 \%$ & $5.15 \%$ & $15.59 \%$ & $2.91 \%$ & $56.69 \%$ & $3.71 \%$ \\
2015 & $16.34 \%$ & $1.88 \%$ & $6.08 \%$ & $18.81 \%$ & $3.16 \%$ & $50.08 \%$ & $3.66 \%$ \\
Média & $2014-2016$ & & & & & \\
\hline
\end{tabular}

Fonte: Elaborado pelo autor, dados CONTRADE

Salvo o subsetor de transportes, todos os demais apresentaram taxas médias anuais negativas de crescimento das exportações. As menores taxas foram do setor de uso mistos com 9.50\% a.a., e de Construção e Bens Seriados com 5.05\% a.a.

As perdas do setor de uso misto (Tabela 16) tiveram média de $9.50 \%$ a.a., reduzindo o total exportado de US\$3,079,770.37 mil em 2008 para US\$ 740,185.58 mil em 2016. Uma explicação para essa redução foi a queda das importações da Argentina de US\$ 1,188,390.25 mil para US\$ 85,640.71 mil, cerca de 93\%. Entre os 16 maiores importadores de bens de uso misto do Brasil, o país perdeu mercado em 14 deles, somente as exportações para China e Bolívia tiveram desempenho positivo.

No setor de construção (Tabela 13), o Brasil também acumulou perdas. Em 2016, as exportações caíram para a Argentina (37.17\%), EUA (35.70\%), México (58.39\%), Peru $(25.10 \%)$ e Chile (31.83\%). Esses cinco mercados respondiam por $63.54 \%$ das exportações acumuladas desse subsetor no período.

Nota-se que as causas da redução das exportações totais de bens de capital não podem ser atribuídas somente à crise interna, mas também ao menor dinamismo das importações mundiais do setor no período, que cresceram apenas $0.88 \%$ frente um crescimento de $29.37 \%$ no período anterior. Além disso, outro fator relevante para explicar a redução das exportações brasileiras foi o aumento das exportações da China e o seu 
ganho de market share no mercados da América Latina ${ }^{6}$ e Caribe e América do Norte (LAUTENSCHLAGER, 2017).

\section{CONSIDERAÇÕES FINAIS}

A crise internacional de 2008-2009 e a crise econômica e política interna de 20142016 afetaram os fluxos comerciais de bens de capital do Brasil. No entanto, esses dois eventos não foram as únicas razões que explicam o desempenho desses fluxos.

Tanto as exportações como as importações brasileiras de todos os subsetores analisados estão concentradas em poucos países. Os seis maiores parceiros comerciais do país representam mais de $50 \%$ dos fluxos comerciais, seja importação, seja exportação, para todos os subsetores analisados.

Entre os principais compradores de bens de capital do Brasil destacam-se a Argentina, os Estados Unidos e o Chile. Exceto no subsetor bens de capital agrícola no qual o Chile ocupa a nona posição, esses três países aparecem entre os cinco principais compradores brasileiros em todos os outros subsetores analisados. Em razão dessa concentração de mercado, as exportações brasileiras ficam condicionadas ao desempenho dessas economias.

Uma das explicações da redução das exportações em 2009 foi a crise internacional que afetou severamente as importações americanas. Considerando todo o setor de bens de capital, as importações dos EUA ainda não haviam se recuperado totalmente em 2016 e continuavam em patamares menores do que em 2008. Já o baixo crescimento da Argentina, a partir de 2012, com média anual negativa para o período, também foi relevante para explicar a redução das exportações brasileiras desse período.

Outro fator foi a perda de participação de mercado do Brasil nos seis principais compradores do país, destacadamente, o resultado com relação à Argentina. A perda de participação do país pode ter sido motivada pelo dinamismo das exportações chinesas do setor e do ganho de mercado desse país na América Latina e América do Norte.

Além de concentradas em poucos mercados, as exportações também ficaram concentradas no setor de transportes que representava cerca de $50 \%$ do total no triênio de 2014-2016 e com participação de 45\% no acumulado do período. O Brasil destaca-se na produção desse setor. Os subsetores de bens seriados e bens para a construção também são muito relevantes comparativamente aos demais subsetores.

O setor de energia elétrica, considerado de alta intensidade tecnológica, no entanto, possui uma pequena importância nas exportações brasileiras e também na produção nacional, mas, por outro lado, ocupa um espaço importante nas importações do país.

6. Segundo Lautenschlager (2017, p. 217), "Na Argentina, é notável que o Brasil não foi o único a perder espaço nas importações de bens de capital do país. Entre os cinco maiores fornecedores desses produtos ao mercado argentino, Estados Unidos e França tiveram diminuições marcantes de seus market shares. $\mathrm{O}$ país beneficiário, como poderia ser esperado, foi a China, cuja participação de mercado cresceu nada menos que 8,6 p.p. no período. Contudo, chama a atenção o fato de que a perda brasileira de presença no mercado argentino concentrou-se no setor de equipamentos eletrônicos ou de comunicação, no qual se perdeu nada menos do que 30,4 p.p. de market share. De forma similar, a França foi quem sofreu com as vendas de outros equipamentos de transporte (-21,1 p.p.). Os Estados Unidos, por sua vez, tiveram prejuízos distribuídos mais uniformemente entre os setores." O autor não adota as mesmas definições para o conjunto dos bens analisados, mas a tendência parece ser a mesma. 
O Brasil possui uma pequena participação nos fluxos internacionais do setor, ocupando apenas a $23^{\circ}$ no acumulado entre 2008-2016. Mesmo assim, era o segundo maior exportador do BRICS atrás apenas da China, a maior exportadora mundial. Em relação às importações, o Brasil ocupava a penúltima posição atrás apenas da África do Sul.

Entre os seis principais importadores de bens de capital do Brasil, o único em que o país possui elevado market-share é a Argentina. Nos subsetores de bens Agrícolas, Construção e Transporte, a participação de mercado brasileira foi superior a $40 \%$ no período.

O Brasil é um importador líquido de bens de capital e apresenta consistentemente déficits na balança comercial do setor. Somente o subsetor de transporte possui um desempenho positivo e acumulou superávits comerciais. A cobertura dos déficits setoriais dependeu do saldo positivo das exportações de commodities. 


\section{REFERÊNCIAS}

ABREU, M. P.; WERNECK, R. L. F. Estabilização, Abertura e Privatização, 1990-1994. ABREU. M. P. A ordem do progresso. Rio de Janeiro: Elsevier, 2014. p. 313-330.

ARAUJO, B. Estudos setoriais de inovação: Indústria de bens de capital. Belo Horizonte: Agência Brasileira de Desenvolvimento Industrail, 2009. Disponível em:

http://www.abdi.com.br/Estudo/Indústria de Bens de Capital.pdf. Acesso em: 14 set. 2017.

CASTRO, L. B. Privatização, abertura e desindexação: a primeira metade dos anos 90. Economia Brasileira Contemporânea. São Paulo: Elsevier, 2011. p. 131-163.

DELGADO, G. C. Especialização primária como limite ao desenvolvimento. Desenvolvimento em debate, v. 1, n. 2, p. p.111-125, 2010. Disponível em: http://desenvolvimentoemdebate.ie.ufrj.br/pdf/dd_guilherme.pdf. Acesso em: 5 jan. 2018.

GRAMS, J. C. et al. Competitividade das Exportações da Indústria Automobilística Brasileira: Uma Análise Constant Market Share. Desenvolvimento em Questão, v. 11, n. 23, p. 247, 17 jun. 2013. Disponível em:

https://www.revistas.unijui.edu.br/index.php/desenvolvimentoemquestao/article/view/421. Acesso em: 15 fev. 2019.

HIDALGO, Á. B.; FEISTEL, P. R. Mudanças na estrutura do comércio exterior brasileiro: uma análise sob a ótica da teoria de Heckscher-Ohlin. Estudos Econômicos (São Paulo), v. 43, n. 1, p. 79-108, mar. 2013. Disponível em: http://www.scielo.br/scielo.php?script=sci_arttext\&pid=S0101$41612013000100004 \&$ Ing=pt\&tlng=pt. Acesso em: 5 jan. 2018.

LAFAY, G. The measurement of revealed comparative advantages. DAGENAIS, $M$. G.; MUET, P.-A. (ed.). International Trade Modelling. London: Springer-Science and Business Media, 1992. p. 209-236.

LAPLANE, M.; SARTI, F. Investimento Direto Estrangeiro e o Impacto na Balança Comercial nos Anos 90. Texto para a discussão $n^{\circ} 626$ - IPEA, 1999. Disponível em: http://www.ipea.gov.br/agencia/images/stories/PDFs/TDs/td_0629.pdf. Acesso em: 8 set. 2017.

LAUTENSCHLAGER, A. As exportações mundiais de bens de capital no contexto da crise financeira internacional. BNDES Setorial, v. 45, p. 1989-225, 2017. Disponível em: https://web.bndes.gov.br/bib/jspui/handle/1408/11755. Acesso em: 3 fev. 2019.

NEGRI, F.; ALVARENGA, G. V. A primarização da pauta de exportação brasileira: ainda um dilema. Boletim Radar, v. 11, 2010. Disponível em:

http://www.ipea.gov.br/portal/images/stories/PDFs/radar/110509_radar13_cap1.pdf. Acesso em: 21 mar. 2018.

OLIVEIRA, A. C. Estrutura e dinâmica do fluxo comercial brasileiro de bens de capital no período 1989-2016. RDE - Revista de Desenvolvimento Econômico, v. 1, n. 42, p. 348368, 2019. Disponível em: https://revistas.unifacs.br/index.php/rde/article/view/5984/3836. Acesso em: 2 out. 2019. 
PEDRO, L. S.; BARROS, D. C. As mudanças estruturais do setor automotivo, os impactos da crise e as perspectivas para o Brasil. BNDES Setorial, v. 34, p. 173-202, 2011.

Disponível em: http://www.bndes.gov.br/bibliotecadigital. Acesso em: 1 fev. 2019.

RESENDE, M. F. C.; ANDERSON, P. Mudanças Estruturais na Indústria Brasileira de Bens de Capital. Texto para a discussão $n^{\circ} 658$ - IPEA, p. 1-56, 1999. Disponível em:

http://www.ipea.gov.br/portal/images/stories/PDFs/TDs/td_0658.pdf. Acesso em: 8 set. 2017.

VERMULM, R. O setor de bens de capital. In: SCHWARTZMAN, S. (Org.). . Ciência e Tecnologia no Brasil: política industrial, mercado de trabalho e instituições de apoio. [S.I.]: Editora Fundação Getúlio Vargas, 1995. p. 149-178.

WEISE, M. R. O comportamento da indústria de bens de capital após a implantação do Plano Real. Revista da FAE, v. 3, n. 3, 2 fev. 2000. Disponível em:

https://revistafae.fae.edu/revistafae/article/view/511. Acesso em: 8 set. 2017. 


\section{ANEXO A}

Tabela 6 - Os 20 principais países de destino das exportações de bens de capital do Brasil - (Mil US\$ 2010 constante)

\begin{tabular}{|c|c|c|c|c|c|c|}
\hline Parceiro & 2008 & 2012 & 2016 & $\begin{array}{c}\text { Acumulado } \\
2008-2016\end{array}$ & $\begin{array}{l}\text { Participação } \\
\text { na pauta }\end{array}$ & Acumulado \\
\hline Argentina & $5,680,769.23$ & $5,339,152.30$ & $3,933,217.21$ & $43,957,509.59$ & $23.08 \%$ & $23.08 \%$ \\
\hline EUA & $5,585,086.77$ & $3,747,992.54$ & $5,081,417.11$ & $37,149,773.19$ & $19.51 \%$ & $42.59 \%$ \\
\hline México & $1,632,342.04$ & $1,482,799.49$ & $1,226,657.20$ & $12,347,778.91$ & $6.48 \%$ & $49.08 \%$ \\
\hline Chile & $1,305,425.56$ & $1,313,833.44$ & $829,697.85$ & $9,615,797.03$ & $5.05 \%$ & $54.12 \%$ \\
\hline Alemanha & $1,199,274.31$ & $1,331,149.43$ & $681,072.25$ & $9,059,598.46$ & $4.76 \%$ & $58.88 \%$ \\
\hline China & $603,490.00$ & 1,209,898.19 & $1,387,499.49$ & $6,628,393.80$ & $3.48 \%$ & $62.36 \%$ \\
\hline Peru & $923,404.59$ & $989,128.82$ & $641,470.97$ & $6,615,773.01$ & $3.47 \%$ & $65.84 \%$ \\
\hline Irlanda & $2,730.54$ & $1,148,417.08$ & $288,487.21$ & $4,457,451.43$ & $2.34 \%$ & $68.18 \%$ \\
\hline Colômbia & $595,207.23$ & $458,699.97$ & $347,064.99$ & $4,184,661.26$ & $2.20 \%$ & $70.37 \%$ \\
\hline Paraguai & $468,666.10$ & $416,225.43$ & $331,672.23$ & $4,068,166.04$ & $2.14 \%$ & $72.51 \%$ \\
\hline Uruguai & $433,503.48$ & $345,719.94$ & $210,585.37$ & $3,148,365.05$ & $1.65 \%$ & $74.16 \%$ \\
\hline Canada & $417,966.52$ & $360,693.25$ & $230,619.60$ & $2,860,546.68$ & $1.50 \%$ & $75.67 \%$ \\
\hline France & $450,267.05$ & $256,325.04$ & $190,651.96$ & $2,785,333.95$ & $1.46 \%$ & $77.13 \%$ \\
\hline Bolívia & $175,312.25$ & $326,518.18$ & $310,184.38$ & $2,533,418.87$ & $1.33 \%$ & $78.46 \%$ \\
\hline Reino Unido & $284,443.26$ & $239,563.51$ & $306,771.94$ & $2,432,292.06$ & $1.28 \%$ & $79.74 \%$ \\
\hline África do Sul & $350,801.27$ & $283,053.39$ & $187,755.88$ & $2,266,213.41$ & $1.19 \%$ & $80.93 \%$ \\
\hline Equador & $364,174.99$ & $212,404.90$ & $135,136.88$ & $2,026,411.27$ & $1.06 \%$ & $81.99 \%$ \\
\hline Itália & $321,827.18$ & $224,315.76$ & $163,720.74$ & $1,910,460.02$ & $1.00 \%$ & $82.99 \%$ \\
\hline
\end{tabular}

Fonte: Resultados da pesquisa, dados CONTRADE 
Tabela 7 - Os 20 principais países de origem das importações de bens de capital do Brasil - (Mil US\$ 2010 constante)

\begin{tabular}{|c|c|c|c|c|c|c|}
\hline Parceiro & 2008 & 2012 & 2016 & $\begin{array}{c}\text { Acumulado } \\
\text { 2008-2016 }\end{array}$ & $\begin{array}{l}\text { Participaçãon } \\
\text { a pauta }\end{array}$ & Acumulado \\
\hline China & $3,109,455.40$ & $5,593,595.92$ & $4,517,296.29$ & $43,595,252.20$ & $16.83 \%$ & $16.83 \%$ \\
\hline EUA & $4,625,322.29$ & $5,552,720.91$ & $3,090,597.11$ & $41,995,778.88$ & $16.22 \%$ & $33.05 \%$ \\
\hline Argentina & $2,380,878.55$ & $3,922,865.79$ & $2,167,476.04$ & $28,489,260.13$ & $11.00 \%$ & $44.05 \%$ \\
\hline Alemanha & $3,540,052.43$ & $3,535,132.44$ & $2,242,092.79$ & $28,051,755.81$ & $10.83 \%$ & $54.88 \%$ \\
\hline Japão & $2,312,761.92$ & $2,213,214.68$ & $1,090,013.92$ & $17,597,459.49$ & $6.80 \%$ & $61.68 \%$ \\
\hline Itália & $1,547,069.62$ & $1,760,532.96$ & $1,101,700.62$ & $14,271,430.02$ & $5.51 \%$ & $67.19 \%$ \\
\hline $\begin{array}{l}\text { Coréia do } \\
\text { Sul }\end{array}$ & $731,037.09$ & $1,508,275.21$ & $1,867,870.33$ & $11,115,996.37$ & $4.29 \%$ & $71.48 \%$ \\
\hline France & $1,180,724.74$ & $1,457,260.98$ & $744,569.31$ & $10,550,776.91$ & $4.07 \%$ & $75.56 \%$ \\
\hline México & $476,369.86$ & $777,160.77$ & $881,204.26$ & $6,594,634.71$ & $2.55 \%$ & $78.10 \%$ \\
\hline Suécia & $693,505.37$ & $808,828.63$ & $370,299.67$ & $6,186,345.83$ & $2.39 \%$ & $80.49 \%$ \\
\hline Tailândia & $399,695.17$ & $806,780.15$ & $378,244.95$ & $4,954,501.11$ & $1.91 \%$ & $82.41 \%$ \\
\hline Spain & $433,741.59$ & $633,416.88$ & $363,186.95$ & $4,668,495.47$ & $1.80 \%$ & $84.21 \%$ \\
\hline Reino Unido & $397,454.18$ & $559,277.61$ & $304,932.32$ & $3,877,745.75$ & $1.50 \%$ & $85.71 \%$ \\
\hline Índia & $149,556.78$ & $489,743.28$ & $236,892.36$ & $2,939,267.56$ & $1.14 \%$ & $86.84 \%$ \\
\hline Suíça & $316,303.99$ & $397,561.11$ & $108,948.60$ & $2,884,628.96$ & $1.11 \%$ & $87.96 \%$ \\
\hline Canada & $226,742.27$ & $252,992.91$ & $113,223.39$ & $2,425,267.73$ & $0.94 \%$ & $88.89 \%$ \\
\hline $\begin{array}{l}\text { Outros países } \\
\text { da Ásia }\end{array}$ & $324,668.95$ & $309,010.08$ & $136,980.73$ & $2,330,326.44$ & $0.90 \%$ & $89.79 \%$ \\
\hline Áustria & $179,596.41$ & $335,903.64$ & $174,662.84$ & $2,271,925.80$ & $0.88 \%$ & $90.67 \%$ \\
\hline Finlândia & $229,669.44$ & $260,819.25$ & $261,644.35$ & $2,152,718.83$ & $0.83 \%$ & $91.50 \%$ \\
\hline $\begin{array}{l}\text { República } \\
\text { Tcheca }\end{array}$ & $161,122.23$ & $214,289.85$ & $127,497.36$ & $1,738,426.01$ & $0.67 \%$ & $92.17 \%$ \\
\hline
\end{tabular}

Fonte: Resultados da pesquisa, dados do CONTRADE 
Tabela 8 - Principais exportadores mundiais e países do BRICS (Mil US\$2010 constante)

\begin{tabular}{|c|c|c|c|c|c|}
\hline & Países & 2008 & 2009 & 2010 & 2011 \\
\hline 1 & China & $324,218,259.70$ & $309,141,289.45$ & $428,231,721.61$ & $506,282,822.12$ \\
\hline 2 & Alemanha & $276,583,821.30$ & $198,309,126.92$ & $233,747,726.01$ & $287,386,837.64$ \\
\hline 3 & EUA & $215,163,736.95$ & $175,115,634.59$ & $206,267,307.29$ & $232,654,116.12$ \\
\hline 4 & Japão & $151,703,309.18$ & $116,936,229.35$ & $163,628,881.64$ & $182,882,114.28$ \\
\hline 5 & França & $108,370,043.95$ & $85,919,384.17$ & $96,887,462.29$ & $112,826,495.00$ \\
\hline 6 & México & $64,368,556.56$ & $60,841,462.74$ & $88,785,940.66$ & $101,352,415.94$ \\
\hline 7 & Itália & $92,976,468.17$ & $66,959,702.61$ & $73,312,960.20$ & $88,776,668.65$ \\
\hline 8 & $\begin{array}{l}\text { Coréia do } \\
\text { Sul }\end{array}$ & $69,981,978.14$ & $57,777,111.24$ & $71,954,667.20$ & $85,347,599.21$ \\
\hline 23 & Brasil & $25,193,017.15$ & $16,707,019.20$ & $21,359,011.40$ & $25,717,015.15$ \\
\hline 26 & Índia & $12,659,322.45$ & $10,685,553.87$ & $14,833,891.02$ & $18,956,801.42$ \\
\hline 34 & $\begin{array}{l}\text { África do } \\
\text { Sul }\end{array}$ & $7,900,299.02$ & $5,692,784.25$ & $7,038,426.28$ & 8,515,358.79 \\
\hline \multirow[t]{2}{*}{44} & Rússia & $3,326,152.20$ & $3,316,854.29$ & $3,437,384.54$ & $6,139,841.44$ \\
\hline & Países & 2013 & 2014 & 2015 & 2016 \\
\hline 1 & China & $586,452,221.90$ & $627,899,907.58$ & $604,360,994.67$ & $578,649,099.21$ \\
\hline 2 & Alemanha & $289,351,287.72$ & $301,351,521.73$ & $266,789,173.01$ & $263,954,001.97$ \\
\hline 3 & EUA & $256,621,603.70$ & $273,317,620.46$ & $256,426,301.71$ & $242,234,477.98$ \\
\hline 4 & Japão & $158,425,367.28$ & $154,344,333.86$ & $133,948,630.39$ & $132,629,250.25$ \\
\hline 5 & França & $118,052,291.32$ & $125,941,333.67$ & $106,108,363.66$ & $103,925,212.05$ \\
\hline 6 & México & $113,517,707.03$ & $121,637,820.42$ & $131,516,787.03$ & $133,489,440.70$ \\
\hline 7 & Itália & $89,004,397.96$ & $90,621,782.97$ & $78,431,304.71$ & $77,387,337.03$ \\
\hline 8 & $\begin{array}{l}\text { Coréia do } \\
\text { Sul }\end{array}$ & $91,699,993.07$ & $87,045,482.49$ & $79,928,541.02$ & $75,531,248.75$ \\
\hline 23 & Brasil & $22,042,071.93$ & $19,609,085.59$ & $18,369,174.78$ & $19,958,269.91$ \\
\hline 26 & Índia & $19,825,032.24$ & $19,751,206.68$ & $18,807,772.03$ & $18,049,980.98$ \\
\hline 34 & África do Sul & $9,707,987.60$ & $9,543,594.97$ & $7,824,742.33$ & $6,558,185.06$ \\
\hline 44 & Rússia & $5,935,209.60$ & $5,273,468.70$ & $4,157,478.80$ & $4,036,834.28$ \\
\hline
\end{tabular}

Fonte: Resultados da pesquisa, dados do CONTRADE 
Tabela 9 - Principais importadores mundiais e países do BRICS (Mil US $\$ 2010$ constante)

\begin{tabular}{|c|c|c|c|c|c|}
\hline & Países & 2008 & 2009 & 2010 & 2011 \\
\hline & EUA & $323,963,744.94$ & $267,234,989.35$ & $334,221,234.63$ & $384,614,411.14$ \\
\hline 2 & Alemanha & $180,024,287.54$ & $140,405,260.73$ & $169,456,388.10$ & $195,424,209.37$ \\
\hline 3 & China & $93,637,212.64$ & $88,895,495.93$ & $117,218,200.75$ & $133,528,186.60$ \\
\hline 4 & França & $98,788,136.39$ & $75,067,596.95$ & $89,664,672.01$ & $106,419,207.00$ \\
\hline 5 & Canada & $84,506,785.04$ & $65,611,315.99$ & $84,088,698.30$ & $97,260,002.58$ \\
\hline 6 & $\begin{array}{l}\text { Reino } \\
\text { Unido }\end{array}$ & $92,331,432.08$ & $51,612,105.15$ & $84,055,780.65$ & $94,017,421.51$ \\
\hline 7 & México & $58,933,567.70$ & $46,030,383.08$ & $59,121,083.65$ & $68,763,817.88$ \\
\hline 8 & Japão & $56,315,999.17$ & $44,974,185.70$ & $56,748,921.44$ & $69,481,343.10$ \\
\hline 11 & Rússia & $60,409,703.48$ & $30,674,353.73$ & $45,421,067.36$ & $67,285,368.91$ \\
\hline 19 & Índia & 0.00 & $28,507,261.42$ & $32,754,077.01$ & $36,245,798.22$ \\
\hline 23 & Brasil & $25,594,336.99$ & $20,245,458.48$ & $28,063,954.53$ & $33,622,632.27$ \\
\hline \multirow[t]{2}{*}{37} & $\begin{array}{l}\text { África do } \\
\text { Sul }\end{array}$ & $15,897,494.79$ & $11,221,117.92$ & $14,002,694.49$ & $18,130,319.03$ \\
\hline & Países & 2013 & 2014 & 2015 & 2016 \\
\hline 1 & EUA & $418,059,252.45$ & $458,798,746.86$ & $473,006,660.46$ & $456,185,084.12$ \\
\hline 2 & Alemanha & $189,445,996.94$ & $199,806,316.35$ & $178,992,293.64$ & $181,736,957.56$ \\
\hline 3 & China & $132,024,349.96$ & $142,658,191.14$ & $124,108,320.52$ & $132,331,543.54$ \\
\hline 4 & França & $100,048,028.89$ & $98,003,386.08$ & $87,642,164.07$ & $91,443,860.17$ \\
\hline 5 & Canada & $101,061,068.19$ & $102,042,526.44$ & $96,902,485.20$ & $95,979,678.91$ \\
\hline 6 & $\begin{array}{l}\text { Reino } \\
\text { Unido }\end{array}$ & $89,820,739.77$ & $105,768,818.88$ & $100,745,334.82$ & $100,745,082.38$ \\
\hline 7 & México & $79,368,544.11$ & $83,207,306.64$ & $84,751,259.54$ & $82,094,039.43$ \\
\hline 8 & Japão & $79,445,845.50$ & $82,159,433.63$ & $72,052,526.88$ & $73,414,947.60$ \\
\hline 11 & Rússia & $75,888,776.48$ & $69,572,061.89$ & $40,887,362.41$ & $38,365,580.52$ \\
\hline 19 & Índia & $36,730,640.02$ & $37,743,725.77$ & $38,945,985.23$ & $36,936,160.02$ \\
\hline 23 & Brasil & $37,735,148.46$ & $34,524,020.45$ & $26,411,379.30$ & $22,366,192.81$ \\
\hline 37 & $\begin{array}{l}\text { África do } \\
\text { Sul }\end{array}$ & $17,266,468.01$ & $15,853,581.63$ & $14,525,233.15$ & $12,637,743.01$ \\
\hline
\end{tabular}

Fonte: Resultados da pesquisa, dados do CONTRADE 
Tabela 10 - Bens de Capital Seriados - Importações Mundiais, Exportações Brasil, Participação de Mercado (Mil US\$ 2010 constante)

\begin{tabular}{|c|c|c|c|c|c|}
\hline & & EUA & Alemanha & China & México \\
\hline \multirow{3}{*}{$\begin{array}{l}2008- \\
2010\end{array}$} & Importação Total BK & $49,885,446.88$ & $29,990,053.93$ & $31,930,840.54$ & $12,204,196.36$ \\
\hline & Exportação Brasil BK & $745,565.81$ & $314,664.97$ & $80,934.88$ & $225,271.28$ \\
\hline & Market share & $1.49 \%$ & $1.05 \%$ & $0.25 \%$ & $1.85 \%$ \\
\hline \multirow{3}{*}{$\begin{array}{l}2011- \\
2013\end{array}$} & Importação Total BK & $65,907,459.73$ & $36,844,783.03$ & $42,055,526.33$ & $16,931,857.08$ \\
\hline & Exportação Brasil BK & $900,507.98$ & $361,916.53$ & $123,026.80$ & $234,601.16$ \\
\hline & Market share & $1.37 \%$ & $0.98 \%$ & $0.29 \%$ & $1.39 \%$ \\
\hline \multirow{8}{*}{$\begin{array}{l}2014- \\
2016\end{array}$} & Importação Total BK & $74,460,557.43$ & $36,514,406.77$ & $37,648,279.50$ & $20,036,432.49$ \\
\hline & Exportação BK Brasil & $752,065.70$ & $250,641.29$ & $105,605.73$ & $261,097.13$ \\
\hline & Market share & $1.01 \%$ & $0.69 \%$ & $0.28 \%$ & $1.30 \%$ \\
\hline & $\begin{array}{l}\text { Crescimento importações } \\
\text { BK do período } 1 \text { para o } 2\end{array}$ & $32.12 \%$ & $22.86 \%$ & $31.71 \%$ & $38.74 \%$ \\
\hline & $\begin{array}{l}\text { Crescimento Exportações } \\
\text { do Brasil de BK do período } 1 \\
\text { para o } 2\end{array}$ & $20.78 \%$ & $15.02 \%$ & $52.01 \%$ & $4.14 \%$ \\
\hline & $\begin{array}{l}\text { Crescimento importações } \\
\text { BK do período } 2 \text { para o } 3\end{array}$ & $12.98 \%$ & $-0.90 \%$ & $-10.48 \%$ & $18.34 \%$ \\
\hline & $\begin{array}{l}\text { Crescimento Exportações } \\
\text { do Brasil BK do período } 2 \\
\text { para o } 3\end{array}$ & $-16.48 \%$ & $-30.75 \%$ & $-14.16 \%$ & $11.29 \%$ \\
\hline & & Argentina & Chile & $\begin{array}{c}\text { Total BK } \\
\text { mundo setor }\end{array}$ & $\begin{array}{c}\text { Total } 6 \\
\text { maiores setor }\end{array}$ \\
\hline 2008 & Importação Total BK & $2,120,081.36$ & $1,817,715.95$ & $378,987,452.30$ & $127,948,335.01$ \\
\hline- & Exportação Brasil BK & $432,577.40$ & $104,450.43$ & $3,242,827.33$ & $1,903,464.77$ \\
\hline 2010 & Market share & $20.40 \%$ & $5.75 \%$ & $0.86 \%$ & $1.49 \%$ \\
\hline 2011 & Importação Total BK & $2,799,077.86$ & $2,619,595.36$ & $479,925,603.10$ & $167,158,299.39$ \\
\hline- & Exportação Brasil BK & $568,414.13$ & $120,865.08$ & 3,852,557.39 & $2,309,331.68$ \\
\hline 2013 & Market share & $20.31 \%$ & $4.61 \%$ & $0.80 \%$ & $1.38 \%$ \\
\hline 2014 & Importação Total BK & $2,541,882.65$ & $2,183,399.03$ & $474,589,952.57$ & $173,384,957.88$ \\
\hline- & Exportação BK Brasil & $371,466.57$ & $99,275.32$ & $3,154,765.44$ & $1,088,086.04$ \\
\hline \multirow[t]{5}{*}{2016} & Market share & $14.61 \%$ & $4.55 \%$ & $0.66 \%$ & $0.63 \%$ \\
\hline & $\begin{array}{l}\text { Crescimento importações BK } \\
\text { do período } 1 \text { para o } 2\end{array}$ & $32.03 \%$ & $44.11 \%$ & $26.63 \%$ & $30.65 \%$ \\
\hline & $\begin{array}{l}\text { Crescimento Exportações do } \\
\text { Brasil de BK do período } 1 \\
\text { para o } 2\end{array}$ & $31.40 \%$ & $15.72 \%$ & $18.80 \%$ & $21.32 \%$ \\
\hline & $\begin{array}{l}\text { Crescimento importações BK } \\
\text { do período } 2 \text { para o } 3\end{array}$ & $-9.19 \%$ & $-16.65 \%$ & $-1.11 \%$ & $3.73 \%$ \\
\hline & $\begin{array}{l}\text { Crescimento Exportações do } \\
\text { Brasil BK do período } 2 \text { para o } \\
3\end{array}$ & $-34.65 \%$ & $-17.86 \%$ & $-18.11 \%$ & $-52.88 \%$ \\
\hline
\end{tabular}

Fonte: Resultados da pesquisa, dados CONTRADE 
Tabela 11 - Bens de Capital Não Seriados - Importações Mundiais, Exportações Brasil, Participação de Mercado (Mil US\$ 2010 constante)

\begin{tabular}{|c|c|c|c|c|c|}
\hline & & EUA & Alemanha & China & México \\
\hline \multirow{3}{*}{$\begin{array}{l}2008- \\
2010\end{array}$} & Importação Total BK & $5,286,128.40$ & $2,500,753.38$ & $5,824,425.25$ & $2,070,807.81$ \\
\hline & Exportação Brasil BK & $63,990.66$ & $17,605.33$ & $38,242.62$ & $33,556.59$ \\
\hline & Market share & $1.21 \%$ & $0.70 \%$ & $0.66 \%$ & $1.62 \%$ \\
\hline \multirow{3}{*}{$\begin{array}{l}2011- \\
2013\end{array}$} & Importação Total BK & $5,850,519.71$ & $2,868,956.75$ & $5,509,548.91$ & $2,487,338.60$ \\
\hline & Exportação Brasil BK & $82,078.72$ & $5,590.50$ & $28,211.09$ & $21,848.15$ \\
\hline & Market share & $1.40 \%$ & $0.19 \%$ & $0.51 \%$ & $0.88 \%$ \\
\hline \multirow{8}{*}{$\begin{array}{l}2014- \\
2016\end{array}$} & Importação Total BK & $6,463,248.74$ & $2,660,214.51$ & $4,221,412.66$ & $2,652,744.55$ \\
\hline & Exportação BK Brasil & $48,904.54$ & $5,288.09$ & $6,167.45$ & $28,892.56$ \\
\hline & Market share & $0.76 \%$ & $0.20 \%$ & $0.15 \%$ & $1.09 \%$ \\
\hline & $\begin{array}{l}\text { Crescimento importações } \\
\text { BK do período } 1 \text { para o } 2\end{array}$ & $10.68 \%$ & $14.72 \%$ & $-5.41 \%$ & $20.11 \%$ \\
\hline & $\begin{array}{l}\text { Crescimento Exportações } \\
\text { do Brasil de BK do período } \\
1 \text { para o } 2\end{array}$ & $28.27 \%$ & $-68.25 \%$ & $-26.23 \%$ & $-34.89 \%$ \\
\hline & $\begin{array}{l}\text { Crescimento importações } \\
\text { BK do período } 2 \text { para o } 3\end{array}$ & $10.47 \%$ & $-7.28 \%$ & $-23.38 \%$ & $6.65 \%$ \\
\hline & $\begin{array}{l}\text { Crescimento Exportações } \\
\text { do Brasil BK do período } 2 \\
\text { para o } 3\end{array}$ & $-40.42 \%$ & $-5.41 \%$ & $-78.14 \%$ & $32.24 \%$ \\
\hline & & Argentina & Chile & $\begin{array}{c}\text { Total BK } \\
\text { mundo setor }\end{array}$ & $\begin{array}{c}\text { Total } 6 \\
\text { maiores setor }\end{array}$ \\
\hline \multirow{3}{*}{$\begin{array}{l}2008- \\
2010\end{array}$} & Importação Total BK & $313,814.00$ & $652,660.78$ & $59,960,355.47$ & $16,648,589.64$ \\
\hline & Exportação Brasil BK & $34,547.54$ & $46,772.99$ & $510,006.90$ & $234,715.73$ \\
\hline & Market share & $11.01 \%$ & $7.17 \%$ & $0.85 \%$ & $1.41 \%$ \\
\hline \multirow{3}{*}{$\begin{array}{l}2011- \\
2013\end{array}$} & Importação Total BK & $381,947.98$ & $726,461.47$ & $71,234,701.91$ & $17,824,773.42$ \\
\hline & Exportação Brasil BK & $42,257.78$ & $51,497.89$ & $464,920.75$ & $231,484.12$ \\
\hline & Market share & $11.06 \%$ & $7.09 \%$ & $0.65 \%$ & $1.30 \%$ \\
\hline \multirow{7}{*}{$\begin{array}{l}2014- \\
2016\end{array}$} & Importação Total BK & $327,756.14$ & $631,422.80$ & $66,286,203.96$ & $16,956,799.40$ \\
\hline & Exportação BK Brasil & $36,048.00$ & $32,719.50$ & $363,237.52$ & $109,115.60$ \\
\hline & Market share & $11.00 \%$ & $5.18 \%$ & $0.55 \%$ & $0.64 \%$ \\
\hline & $\begin{array}{l}\text { Crescimento importações BK } \\
\text { do período } 1 \text { para o } 2\end{array}$ & $21.71 \%$ & $11.31 \%$ & $18.80 \%$ & $7.06 \%$ \\
\hline & $\begin{array}{l}\text { Crescimento Exportações do } \\
\text { Brasil de BK do período } 1 \\
\text { para o } 2\end{array}$ & $22.32 \%$ & $10.10 \%$ & $-8.84 \%$ & $-1.38 \%$ \\
\hline & $\begin{array}{l}\text { Crescimento importações BK } \\
\text { do período } 2 \text { para o } 3\end{array}$ & $-14.19 \%$ & $-13.08 \%$ & $-6.95 \%$ & $-4.87 \%$ \\
\hline & $\begin{array}{l}\text { Crescimento Exportações do } \\
\text { Brasil BK do período } 2 \text { para o } \\
3\end{array}$ & $-14.69 \%$ & $-36.46 \%$ & $-21.87 \%$ & $-52.86 \%$ \\
\hline
\end{tabular}

Fonte: Resultados da pesquisa, dados CONTRADE 
Tabela 12 - Bens de Capital Agrícola - Importações Mundiais, Exportações Brasil, Participação de Mercado (Mil US\$ 2010 constante)

\begin{tabular}{|c|c|c|c|c|c|}
\hline & & EUA & Alemanha & China & México \\
\hline \multirow{3}{*}{$\begin{array}{l}2008- \\
2010\end{array}$} & Importação Total BK & $16,251,936.08$ & $10,661,911.48$ & $8,671,919.67$ & $4,646,067.07$ \\
\hline & Exportação Brasil BK & $148,079.82$ & $73,620.16$ & $9,447.53$ & $115,341.22$ \\
\hline & Market share & $0.91 \%$ & $0.69 \%$ & $0.11 \%$ & $2.48 \%$ \\
\hline \multirow{3}{*}{$\begin{array}{l}2011- \\
2013\end{array}$} & Importação Total BK & $22,814,246.99$ & $12,629,285.54$ & $11,277,982.92$ & $6,153,244.26$ \\
\hline & Exportação Brasil BK & $184,098.47$ & $47,669.98$ & $5,887.19$ & $80,622.15$ \\
\hline & Market share & $0.81 \%$ & $0.38 \%$ & $0.05 \%$ & $1.31 \%$ \\
\hline \multirow{8}{*}{$\begin{array}{l}2014- \\
2016\end{array}$} & Importação Total BK & $25,416,851.16$ & $12,678,644.73$ & $11,207,936.54$ & $7,381,961.85$ \\
\hline & Exportação BK Brasil & $166,789.94$ & $22,824.13$ & $4,266.82$ & $68,242.25$ \\
\hline & Market share & $0.66 \%$ & $0.18 \%$ & $0.04 \%$ & $0.92 \%$ \\
\hline & $\begin{array}{l}\text { Crescimento importações } \\
\text { BK do período } 1 \text { para o } 2\end{array}$ & $40.38 \%$ & $18.45 \%$ & $30.05 \%$ & $32.44 \%$ \\
\hline & $\begin{array}{l}\text { Crescimento Exportações } \\
\text { do Brasil de BK do período } 1 \\
\text { para o } 2\end{array}$ & $24.32 \%$ & $-35.25 \%$ & $-37.69 \%$ & $-30.10 \%$ \\
\hline & $\begin{array}{l}\text { Crescimento importações } \\
\text { BK do período } 2 \text { para o } 3\end{array}$ & $11.41 \%$ & $0.39 \%$ & $-0.62 \%$ & $19.97 \%$ \\
\hline & $\begin{array}{l}\text { Crescimento Exportações } \\
\text { do Brasil BK do período } 2 \\
\text { para o } 3\end{array}$ & $-9.40 \%$ & $-52.12 \%$ & $-27.52 \%$ & $-15.36 \%$ \\
\hline & & Argentina & Chile & $\begin{array}{l}\text { Total BK } \\
\text { mundo setor }\end{array}$ & $\begin{array}{l}\text { Total } 6 \\
\text { maiores setor }\end{array}$ \\
\hline \multirow{3}{*}{$\begin{array}{l}2008- \\
2010\end{array}$} & Importação Total BK & $915,073.90$ & $643,928.70$ & $132,660,886.31$ & $41,790,836.90$ \\
\hline & Exportação Brasil BK & $355,736.48$ & $26,269.93$ & $1,272,256.77$ & $728,495.13$ \\
\hline & Market share & $38.88 \%$ & $4.08 \%$ & $0.96 \%$ & $1.74 \%$ \\
\hline \multirow{3}{*}{$\begin{array}{l}2011- \\
2013\end{array}$} & Importação Total BK & $1,219,868.48$ & $892,408.22$ & $164,347,682.36$ & $54,987,036.41$ \\
\hline & Exportação Brasil BK & $512,375.66$ & $30,974.03$ & $1,496,617.73$ & $861,627.48$ \\
\hline & Market share & $42.00 \%$ & $3.47 \%$ & $0.91 \%$ & $1.57 \%$ \\
\hline \multirow{7}{*}{$\begin{array}{l}2014- \\
2016\end{array}$} & Importação Total BK & $944,375.36$ & $682,348.20$ & $163,669,254.17$ & $58,312,117.85$ \\
\hline & Exportação BK Brasil & $365,885.51$ & $28,324.10$ & $1,173,283.43$ & $489,542.80$ \\
\hline & Market share & $38.74 \%$ & $4.15 \%$ & $0.72 \%$ & $0.84 \%$ \\
\hline & $\begin{array}{l}\text { Crescimento importações BK } \\
\text { do período } 1 \text { para o } 2\end{array}$ & $33.31 \%$ & $38.59 \%$ & $23.89 \%$ & $31.58 \%$ \\
\hline & $\begin{array}{l}\text { Crescimento Exportações do } \\
\text { Brasil de BK do período } 1 \\
\text { para o } 2\end{array}$ & $44.03 \%$ & $17.91 \%$ & $17.63 \%$ & $18.27 \%$ \\
\hline & $\begin{array}{l}\text { Crescimento importações BK } \\
\text { do período } 2 \text { para o } 3\end{array}$ & $-22.58 \%$ & $-23.54 \%$ & $-0.41 \%$ & $6.05 \%$ \\
\hline & $\begin{array}{l}\text { Crescimento Exportações do } \\
\text { Brasil BK do período } 2 \text { para o } \\
3\end{array}$ & $-28.59 \%$ & $-8.56 \%$ & $-21.60 \%$ & $-43.18 \%$ \\
\hline
\end{tabular}

Fonte: Resultados da pesquisa, dados CONTRADE 
Tabela 13 - Bens de Capital Construção - Importações Mundiais, Exportações Brasil, Participação de Mercado (Mil US\$ 2010 constante)

\begin{tabular}{|c|c|c|c|c|c|}
\hline & & EUA & Alemanha & China & México \\
\hline \multirow{3}{*}{$\begin{array}{l}2008- \\
2010\end{array}$} & Importação Total BK & $33,906,401.61$ & $23,358,224.02$ & $15,690,640.85$ & $11,137,787.91$ \\
\hline & Exportação Brasil BK & $671,575.30$ & $115,266.99$ & $27,196.95$ & $369,531.63$ \\
\hline & Market share & $1.98 \%$ & $0.49 \%$ & $0.17 \%$ & $3.32 \%$ \\
\hline \multirow{3}{*}{$\begin{array}{l}2011- \\
2013\end{array}$} & Importação Total BK & $50,006,767.42$ & $29,913,291.06$ & $22,753,764.03$ & $16,666,613.28$ \\
\hline & Exportação Brasil BK & $776,320.88$ & $111,192.43$ & $40,121.71$ & $410,026.84$ \\
\hline & Market share & $1.55 \%$ & $0.37 \%$ & $0.18 \%$ & $2.46 \%$ \\
\hline \multirow{8}{*}{$\begin{array}{l}2014- \\
2016\end{array}$} & Importação Total BK & $58,549,048.84$ & $31,499,933.85$ & $22,563,661.06$ & $18,525,264.25$ \\
\hline & Exportação BK Brasil & $732,679.08$ & $68,347.57$ & $13,683.45$ & $276,200.55$ \\
\hline & Market share & $1.25 \%$ & $0.22 \%$ & $0.06 \%$ & $1.49 \%$ \\
\hline & $\begin{array}{l}\text { Crescimento importações BK } \\
\text { do período } 1 \text { para o } 2\end{array}$ & $47.48 \%$ & $28.06 \%$ & $45.01 \%$ & $49.64 \%$ \\
\hline & $\begin{array}{l}\text { Crescimento Exportações do } \\
\text { Brasil de BK do período } 1 \\
\text { para o } 2\end{array}$ & $15.60 \%$ & $-3.53 \%$ & $47.52 \%$ & $10.96 \%$ \\
\hline & $\begin{array}{l}\text { Crescimento importações BK } \\
\text { do período } 2 \text { para o } 3\end{array}$ & $17.08 \%$ & $5.30 \%$ & $-0.84 \%$ & $11.15 \%$ \\
\hline & $\begin{array}{l}\text { Crescimento Exportações do } \\
\text { Brasil BK do período } 2 \text { para o } \\
3\end{array}$ & $-5.62 \%$ & $-38.53 \%$ & $-65.90 \%$ & $-32.64 \%$ \\
\hline & & Argentina & Chile & $\begin{array}{c}\text { Total BK } \\
\text { mundo setor }\end{array}$ & $\begin{array}{c}\text { Total } 6 \\
\text { maiores setor }\end{array}$ \\
\hline \multirow{3}{*}{$\begin{array}{l}2008- \\
2010\end{array}$} & Importação Total BK & $2,709,577.44$ & $1,648,366.44$ & $246,824,268.01$ & $88,450,998.28$ \\
\hline & Exportação Brasil BK & $1,376,417.03$ & $137,677.62$ & 4,217,141.89 & $2,697,665.52$ \\
\hline & Market share & $50.80 \%$ & $8.35 \%$ & $1.71 \%$ & $3.05 \%$ \\
\hline \multirow{3}{*}{$\begin{array}{l}2011- \\
2013\end{array}$} & Importação Total BK & $3,788,081.63$ & $2,626,640.85$ & $336,953,066.43$ & $125,755,158.27$ \\
\hline & Exportação Brasil BK & $1,868,348.42$ & $178,885.06$ & 5,409,559.11 & 3,384,895.33 \\
\hline & Market share & $49.32 \%$ & $6.81 \%$ & $1.61 \%$ & $2.69 \%$ \\
\hline \multirow{7}{*}{$\begin{array}{l}2014- \\
2016\end{array}$} & Importação Total BK & $2,623,762.51$ & $1,299,853.36$ & $325,437,079.97$ & $135,061,523.87$ \\
\hline & Exportação BK Brasil & $1,034,733.50$ & $109,912.74$ & 3,633,273.65 & $1,392,965.08$ \\
\hline & Market share & $39.44 \%$ & $8.46 \%$ & $1.12 \%$ & $1.03 \%$ \\
\hline & $\begin{array}{l}\text { Crescimento importações BK } \\
\text { do período } 1 \text { para o } 2\end{array}$ & $39.80 \%$ & $59.35 \%$ & $36.52 \%$ & $42.17 \%$ \\
\hline & $\begin{array}{l}\text { Crescimento Exportações do } \\
\text { Brasil de BK do período } 1 \\
\text { para o } 2\end{array}$ & $35.74 \%$ & $29.93 \%$ & $28.28 \%$ & $25.47 \%$ \\
\hline & $\begin{array}{l}\text { Crescimento importações BK } \\
\text { do período } 2 \text { para o } 3\end{array}$ & $-30.74 \%$ & $-50.51 \%$ & $-3.42 \%$ & $7.40 \%$ \\
\hline & $\begin{array}{l}\text { Crescimento Exportações do } \\
\text { Brasil BK do período } 2 \text { para o } \\
3\end{array}$ & $-44.62 \%$ & $-38.56 \%$ & $-32.84 \%$ & $-58.85 \%$ \\
\hline
\end{tabular}

Fonte: Resultados da pesquisa, dados CONTRADE 
Tabela 14 - Bens de Capital Elétrico - Importações Mundiais, Exportações Brasil, Participação de Mercado (Mil US\$ 2010 constante)

\begin{tabular}{|c|c|c|c|c|c|}
\hline & & EUA & Alemanha & China & México \\
\hline \multirow{3}{*}{$\begin{array}{l}2008- \\
2010\end{array}$} & Importação Total BK & $19,121,088.99$ & $9,818,274.25$ & $9,943,215.05$ & $3,966,000.47$ \\
\hline & Exportação Brasil BK & $192,804.22$ & $30,903.04$ & $9,835.07$ & $41,366.41$ \\
\hline & Market share & $1.01 \%$ & $0.31 \%$ & $0.10 \%$ & $1.04 \%$ \\
\hline \multirow{3}{*}{$\begin{array}{l}2011- \\
2013\end{array}$} & Importação Total BK & $23,800,718.01$ & $12,238,304.47$ & $11,862,652.52$ & $5,305,302.44$ \\
\hline & Exportação Brasil BK & $141,238.94$ & $16,936.12$ & $14,158.01$ & $27,037.73$ \\
\hline & Market share & $0.59 \%$ & $0.14 \%$ & $0.12 \%$ & $0.51 \%$ \\
\hline \multirow{7}{*}{$\begin{array}{l}2014- \\
2016\end{array}$} & Importação Total BK (4) & $28,236,108.27$ & $13,079,703.90$ & $12,569,873.48$ & $6,051,364.05$ \\
\hline & Exportação BK Brasil (5) & $107,177.98$ & $10,526.22$ & $38,380.84$ & $23,042.24$ \\
\hline & Market share (6) & $0.38 \%$ & $0.08 \%$ & $0.31 \%$ & $0.38 \%$ \\
\hline & $\begin{array}{l}\text { Crescimento importações BK } \\
\text { do período } 1 \text { para o } 2\end{array}$ & $24.47 \%$ & $24.65 \%$ & $19.30 \%$ & $33.77 \%$ \\
\hline & $\begin{array}{l}\text { Crescimento Exportações do } \\
\text { Brasil de BK do período } 1 \\
\text { para o } 2\end{array}$ & $-26.74 \%$ & $-45.20 \%$ & $43.95 \%$ & $-34.64 \%$ \\
\hline & $\begin{array}{l}\text { Crescimento importações BK } \\
\text { do período } 2 \text { para o } 3\end{array}$ & $18.64 \%$ & $6.88 \%$ & $5.96 \%$ & $14.06 \%$ \\
\hline & $\begin{array}{l}\text { Crescimento Exportações do } \\
\text { Brasil BK do período } 2 \text { para o } \\
3\end{array}$ & $-24.12 \%$ & $-37.85 \%$ & $171.09 \%$ & $-14.78 \%$ \\
\hline & & Argentina & Chile & $\begin{array}{c}\text { Total BK } \\
\text { mundo setor }\end{array}$ & $\begin{array}{c}\text { Total } 6 \\
\text { maiores setor }\end{array}$ \\
\hline \multirow{3}{*}{$\begin{array}{l}2008- \\
2010\end{array}$} & Importação Total BK & $546,358.29$ & $423,150.98$ & $121,176,866.64$ & $43,818,088.03$ \\
\hline & Exportação Brasil BK & $79,123.51$ & $67,985.05$ & $785,628.81$ & $422,017.31$ \\
\hline & Market share & $14.48 \%$ & $16.07 \%$ & $0.65 \%$ & $0.96 \%$ \\
\hline \multirow{3}{*}{$\begin{array}{l}2011- \\
2013\end{array}$} & Importação Total BK & $721,359.88$ & $525,487.58$ & $155,691,282.01$ & $54,453,824.91$ \\
\hline & Exportação Brasil BK & $105,477.59$ & $34,883.54$ & $730,175.66$ & $339,731.93$ \\
\hline & Market share & $14.62 \%$ & $6.64 \%$ & $0.47 \%$ & $0.62 \%$ \\
\hline \multirow{7}{*}{$\begin{array}{l}2014- \\
2016\end{array}$} & Importação Total BK (4) & $795,370.18$ & $886,978.54$ & $160,020,173.13$ & $61,619,398.42$ \\
\hline & Exportação BK Brasil (5) & $92,851.74$ & $34,919.13$ & $610,499.69$ & $199,720.18$ \\
\hline & Market share (6) & $11.67 \%$ & $3.94 \%$ & $0.38 \%$ & $0.32 \%$ \\
\hline & $\begin{array}{l}\text { Crescimento importações } \\
\text { BK do período } 1 \text { para o } 2\end{array}$ & $32.03 \%$ & $24.18 \%$ & $28.48 \%$ & $24.27 \%$ \\
\hline & $\begin{array}{l}\text { Crescimento Exportações } \\
\text { do Brasil de BK do período } 1 \\
\text { para o } 2\end{array}$ & $33.31 \%$ & $-48.69 \%$ & $-7.06 \%$ & $-19.50 \%$ \\
\hline & $\begin{array}{l}\text { Crescimento importações } \\
\text { BK do período } 2 \text { para o } 3\end{array}$ & $10.26 \%$ & $68.79 \%$ & $2.78 \%$ & $13.16 \%$ \\
\hline & $\begin{array}{l}\text { Crescimento Exportações } \\
\text { do Brasil BK do período } 2 \\
\text { para o } 3\end{array}$ & $-11.97 \%$ & $0.10 \%$ & $-16.39 \%$ & $-41.21 \%$ \\
\hline
\end{tabular}

Fonte: Resultados da pesquisa, dados CONTRADE 
Tabela 15 - Bens de Capital Transporte - Importações Mundiais, Exportações Brasil, Participação de Mercado (Mil US\$ 2010 constante)

\begin{tabular}{|c|c|c|c|c|c|}
\hline & & EUA & Alemanha & China & México \\
\hline \multirow{3}{*}{$\begin{array}{l}2008- \\
2010\end{array}$} & Importação Total BK & $37,730,830.81$ & $48,630,701.54$ & $16,988,361.13$ & $8,180,443.63$ \\
\hline & Exportação Brasil BK & $1,623,882.19$ & $500,863.16$ & $401,293.83$ & $485,081.57$ \\
\hline & Market share & $4.30 \%$ & $1.03 \%$ & $2.36 \%$ & $5.93 \%$ \\
\hline \multirow{3}{*}{$\begin{array}{l}2011- \\
2013\end{array}$} & Importação Total BK & $53,296,040.11$ & $49,710,275.17$ & $24,332,493.97$ & $11,673,888.44$ \\
\hline & Exportação Brasil BK & $1,538,755.11$ & $616,705.51$ & $659,684.43$ & $647,247.93$ \\
\hline & Market share & $2.89 \%$ & $1.24 \%$ & $2.71 \%$ & $5.54 \%$ \\
\hline \multirow{8}{*}{$\begin{array}{l}2014- \\
2016\end{array}$} & Importação Total BK & $69,361,661.01$ & $42,552,603.40$ & $29,284,863.04$ & $12,287,911.77$ \\
\hline & Exportação BK Brasil & 2,949,382.18 & $314,880.06$ & $549,237.29$ & $559,719.76$ \\
\hline & Market share & $4.25 \%$ & $0.74 \%$ & $1.88 \%$ & $4.56 \%$ \\
\hline & $\begin{array}{l}\text { Crescimento importações } \\
\text { BK do período } 1 \text { para o } 2\end{array}$ & $41.25 \%$ & $2.22 \%$ & $43.23 \%$ & $42.70 \%$ \\
\hline & $\begin{array}{l}\text { Crescimento Exportações } \\
\text { do Brasil de BK do período } 1 \\
\text { para o } 2\end{array}$ & $-5.24 \%$ & $23.13 \%$ & $64.39 \%$ & $33.43 \%$ \\
\hline & $\begin{array}{l}\text { Crescimento importações } \\
\text { BK do período } 2 \text { para o } 3\end{array}$ & $30.14 \%$ & $-14.40 \%$ & $20.35 \%$ & $5.26 \%$ \\
\hline & $\begin{array}{l}\text { Crescimento Exportações } \\
\text { do Brasil BK do período } 2 \\
\text { para o } 3\end{array}$ & $91.67 \%$ & $-48.94 \%$ & $-16.74 \%$ & $-13.52 \%$ \\
\hline & & Argentina & Chile & $\begin{array}{l}\text { Total BK } \\
\text { mundo setor }\end{array}$ & $\begin{array}{l}\text { Total } 6 \\
\text { maiores setor }\end{array}$ \\
\hline \multirow{3}{*}{$\begin{array}{l}2008- \\
2010\end{array}$} & Importação Total BK & $3,851,442.64$ & $3,012,404.74$ & $374,870,451.25$ & $118,394,184.50$ \\
\hline & Exportação Brasil BK & $1,994,117.64$ & $578,503.11$ & 8,752,915.95 & $5,583,741.50$ \\
\hline & Market share & $51.78 \%$ & $19.20 \%$ & $2.33 \%$ & $4.72 \%$ \\
\hline \multirow{3}{*}{$\begin{array}{l}2011- \\
2013\end{array}$} & Importação Total BK & $4,654,092.38$ & $5,235,526.19$ & $477,971,211.85$ & $148,902,316.25$ \\
\hline & Exportação Brasil BK & $2,851,210.48$ & $704,054.00$ & 10,747,297.78 & $7,017,657.46$ \\
\hline & Market share & $61.26 \%$ & $13.45 \%$ & $2.25 \%$ & $4.71 \%$ \\
\hline \multirow{7}{*}{$\begin{array}{l}2014- \\
2016\end{array}$} & Importação Total BK & $4,066,991.25$ & $3,983,062.68$ & $482,910,028.43$ & $161,537,093.15$ \\
\hline & Exportação BK Brasil & $1,914,762.08$ & $499,540.86$ & $9,671,089.13$ & $3,838,140.06$ \\
\hline & Market share & $47.08 \%$ & $12.54 \%$ & $2.00 \%$ & $2.38 \%$ \\
\hline & $\begin{array}{l}\text { Crescimento importações BK } \\
\text { do período } 1 \text { para o } 2\end{array}$ & $20.84 \%$ & $73.80 \%$ & $27.50 \%$ & $25.77 \%$ \\
\hline & $\begin{array}{l}\text { Crescimento Exportações do } \\
\text { Brasil de BK do período } 1 \\
\text { para o } 2\end{array}$ & $42.98 \%$ & $21.70 \%$ & $22.79 \%$ & $25.68 \%$ \\
\hline & $\begin{array}{l}\text { Crescimento importações BK } \\
\text { do período } 2 \text { para o } 3\end{array}$ & $-12.61 \%$ & $-23.92 \%$ & $1.03 \%$ & $8.49 \%$ \\
\hline & $\begin{array}{l}\text { Crescimento Exportações do } \\
\text { Brasil BK do período } 2 \text { para o } \\
3\end{array}$ & $-32.84 \%$ & $-29.05 \%$ & $-10.01 \%$ & $-45.31 \%$ \\
\hline
\end{tabular}

Fonte: Resultados da pesquisa, dados CONTRADE 
Tabela 16 - Bens de Capital Uso Misto - Importações Mundiais, Exportações Brasil, Participação de Mercado (Mil US\$ 2010 constante)

\begin{tabular}{|c|c|c|c|c|c|}
\hline & & EUA & Alemanha & China & México \\
\hline \multirow{3}{*}{$\begin{array}{l}2008- \\
2010\end{array}$} & Importação Total BK & $149,659,137.81$ & $40,958,891.05$ & $11,995,569.10$ & $13,738,709.98$ \\
\hline & Exportação Brasil BK & $318,571.96$ & 83,083.92 & 19,194.93 & $88,250.50$ \\
\hline & Market share & $0.21 \%$ & $0.20 \%$ & $0.16 \%$ & $0.64 \%$ \\
\hline \multirow{3}{*}{$\begin{array}{l}2011- \\
2013\end{array}$} & Importação Total BK & $186,417,642.03$ & $48,749,100.16$ & $15,982,830.73$ & $17,838,919.05$ \\
\hline & Exportação Brasil BK & $192,998.79$ & $59,779.49$ & $37,156.66$ & $111,709.95$ \\
\hline & Market share & $0.10 \%$ & $0.12 \%$ & $0.23 \%$ & $0.63 \%$ \\
\hline \multirow{7}{*}{$\begin{array}{l}2014- \\
2016\end{array}$} & Importação Total BK & $206,320,368.30$ & $51,749,021.20$ & $18,079,407.23$ & $18,845,596.33$ \\
\hline & Exportação BK Brasil & $178,668.36$ & $23,609.50$ & $5,551.46$ & $91,986.48$ \\
\hline & Market share & $0.09 \%$ & $0.05 \%$ & $0.03 \%$ & $0.49 \%$ \\
\hline & $\begin{array}{l}\text { Crescimento importações } \\
\text { BK do período } 1 \text { para o } 2\end{array}$ & $24.56 \%$ & $19.02 \%$ & $33.24 \%$ & $29.84 \%$ \\
\hline & $\begin{array}{l}\text { Crescimento Exportações } \\
\text { do Brasil de BK do período } 1 \\
\text { para o } 2\end{array}$ & $-39.42 \%$ & $-28.05 \%$ & $93.58 \%$ & $26.58 \%$ \\
\hline & $\begin{array}{l}\text { Crescimento importações } \\
\text { BK do período } 2 \text { para o } 3\end{array}$ & $10.68 \%$ & $6.15 \%$ & $13.12 \%$ & $5.64 \%$ \\
\hline & $\begin{array}{l}\text { Crescimento Exportações } \\
\text { do Brasil BK do período } 2 \\
\text { para o } 3\end{array}$ & $-7.43 \%$ & $-60.51 \%$ & $-85.06 \%$ & $-17.66 \%$ \\
\hline & & Argentina & Chile & $\begin{array}{c}\text { Total BK } \\
\text { mundo setor }\end{array}$ & $\begin{array}{c}\text { Total } 6 \\
\text { maiores setor }\end{array}$ \\
\hline \multirow{3}{*}{$\begin{array}{l}2008- \\
2010\end{array}$} & Importação Total BK & $2,831,005.64$ & $2,577,787.08$ & $601,041,074.00$ & $221,761,100.67$ \\
\hline & Exportação Brasil BK & $816,913.88$ & $181,317.41$ & $2,305,571.61$ & $1,507,332.60$ \\
\hline & Market share & $28.86 \%$ & $7.03 \%$ & $0.38 \%$ & $0.68 \%$ \\
\hline \multirow{3}{*}{$\begin{array}{l}2011- \\
2013\end{array}$} & Importação Total BK & $1,886,750.41$ & $4,056,672.59$ & $793,884,288.54$ & $274,931,914.97$ \\
\hline & Exportação Brasil BK & $152,550.74$ & $117,422.38$ & 1,180,899.76 & $671,618.00$ \\
\hline & Market share & $8.09 \%$ & $2.89 \%$ & $0.15 \%$ & $0.24 \%$ \\
\hline \multirow{7}{*}{$\begin{array}{l}2014- \\
2016\end{array}$} & Importação Total BK & $1,714,232.74$ & $3,887,565.71$ & $831,781,176.18$ & $300,596,191.51$ \\
\hline & Exportação BK Brasil & $73,782.25$ & $30,706.84$ & $706,027.89$ & $225,636.54$ \\
\hline & Market share & $4.30 \%$ & $0.79 \%$ & $0.08 \%$ & $0.08 \%$ \\
\hline & $\begin{array}{l}\text { Crescimento importações } \\
\text { BK do período } 1 \text { para o } 2\end{array}$ & $-33.35 \%$ & $57.37 \%$ & $32.08 \%$ & $23.98 \%$ \\
\hline & $\begin{array}{l}\text { Crescimento Exportações } \\
\text { do Brasil de BK do período } 1 \\
\text { para o } 2\end{array}$ & $-81.33 \%$ & $-35.24 \%$ & $-48.78 \%$ & $-55.44 \%$ \\
\hline & $\begin{array}{l}\text { Crescimento importações } \\
\text { BK do período } 2 \text { para o } 3\end{array}$ & $-9.14 \%$ & $-4.17 \%$ & $4.77 \%$ & $9.33 \%$ \\
\hline & $\begin{array}{l}\text { Crescimento Exportações } \\
\text { do Brasil BK do período } 2 \\
\text { para o } 3\end{array}$ & $-51.63 \%$ & $-73.85 \%$ & $-40.21 \%$ & $-66.40 \%$ \\
\hline
\end{tabular}

Fonte - Resultados da pesquisa, dados CONTRADE 